\title{
The Self-declared Islamic State (Da'esh) and Ius ad Bellum under Islamic International Law
}

\author{
Mohamed Elewa Badar*
}

\begin{abstract}
In terms of international law, the militant group which calls itself the Islamic State (Is) naturally poses questions of illegitimacy in the context of the law of belligerency and International humanitarian law (ius in bello). However, the group claims to operate within a distinct and parallel law, i.e. Islamic (international) law and the support it enjoys stems directly from this claim. A focus on public international law alone would thus provide only an external claim to their illegitimacy, one which they and their many supporters would disregard as meaningless, since it could never be above divine commands. In light of this and in light of the fact that in most Muslim majority states, secularism has never obtained the respect it enjoys in the west, it is thus important to ask the questions of the legitimacy of this group, their actions and their political formations from within the norms of Islamic international law. This study therefore essentially aims to provide answers to questions already raised by many scholars and international organisations: What are the justifications for waging war on which the group relies? Are these justifications valid under Islamic international law? Who can declare jihäd and under what conditions? Could their political formation rightfully claim to be a Caliphate
\end{abstract}

Associate Professor and Reader in Comparative and International Criminal Law \& Islamic Law, Northumbria Law School, Northumbria University, Newcastle, UK. Former Judge and Senior Prosecutor, Ministry of Justice Egypt. PhD and LLM, National University of Ireland, Galway; LLB and Bachelor of Police Sciences, Police College, Police Academy, Cairo, Egypt. An earlier draft of this paper was presented at the 7 th Meeting of Parliamentarians for Global Action's Working Group on the Universality of the Rome Statute of the International Criminal Court in the Middle East and North Africa, Panel II: A System of International Justice to Prevent and Counter Violent Extremism, Dakar, Senegal, 8 December 2016; at Brunel University/Brill Nijhoff Publishers international inaugural conference on 'ISIS and Its Implication for Human Rights and Humanitarian Law' London 30 September 2016 and at International Nuremberg Principles Academy's annual forum on Islam and International Criminal Justice, Nuremberg, 13-14 October. The author would like to thank Dr. Mohamed A. 'Arafa of Indiana University Robert H. McKinney Law School, Indianapolis, UsA, Dr. Ahmed Al-Dawoody of the International Committee of the Red Cross and the anonymous reviewers for their comments on an earlier draft of the present article, all errors remain mine.

(C) MOHAMED ELEWA BADAR, 2017 | DOI 10.1163/9789004339033_004

This is an open access chapter distributed under the terms of the CC-BY License. 
under Shariah? Why have the militants been denied the recognition of their chosen name by the vast majority of Muslims worldwide and have rather been branded with the derogatory acronym Da'esh or named 'the modern day Khärijites'? The answers to these questions are crucial because Da'esh recruitment and rallying narrative relies on depicting their struggle as a just and noble jihäd in line with the tenets of Islam. Arguably, this study would also assist any future prosecution of this group. It would help adjudicators in asserting the legitimacy of their judgments, if they were able to prove that such judgments are compatible with the legal and belief systems recognised by the actors at trial.

\section{Keywords}

ISI/ISIL/ISIS/IS/DAESH - Islamic international law (siyar) - defensive and offensive jihād - ius ad bellum - jihādī-Salafism - Khārijites - excommunication (Takfïr) - abode of war (dāral-harb) - abode of Islam (dāral-Islam)

\section{Introduction}

This article is written in the midst of a rapidly developing story, one which involves a Salafi-jihādi insurgent and terrorist group, declaring itself the Islamic State (IS) but referred to as Da'esh by its opponents, who deny its legitimacy. ${ }^{1}$ The tyrannical identity of these Salafi-jihädi insurgents was unknown to the western world until their frightening rise to power began to flag up on its radar in early 2013. Three years on and the harrowing presence of Da'esh could not be more predominant throughout the consciousness of the international community. The rapid development of their power was brought to light when they entered Fallujah at the start of 2014, raising their black flag over the Governorate office and seizing key administrative buildings. ${ }^{2}$

1 The acronym Da'esh comes from al-Dawlah al-Islamìyah fì al-Irāq wa-al-Shām, (i.e. the Islamic State of Iraq and the Levant (ISIL) which was the initial title the militants gave themselves. However, since acronyms are rare in the Arabic language and have an unusual tone for the native speaker, the term Da'esh plays the role of mocking the militants. 'Is' is referred to as the Islamic State of Iraq and Syria (ISIS), the Islamic State of Iraq and the Levant (ISIL) or the Arabic acronym Da'esh. The use of 'Islamic State' in this article in no way acknowledges or accepts the so-called Islamic State's claim as a legitimate 'Caliphate', nor does it support its claims or ambitions in this respect.

2 United Nations Assistance Mission for Iraq Report on the Protection of Civilians in the Noninternational Armed Conflict in Iraq 5June - 6July 2014 (UNAMI/OHCHR July 2014) < www.ohchr. org/En/Countries/MENARegion/Pages/UnAMiHRreports.aspx>. 
The expansionist powers of Da'esh have proven to be impressive, with their territorial control spanning over large parts of north-western Iraq and north-eastern Syria. ${ }^{3}$ In June 2014 they highlighted the strength of their military organisation when they took control of Mosul, Iraq's second largest city, distilling fear throughout humanity as the Iraqi Security forces (ISF) ${ }^{4}$ fled for their lives. ${ }^{5}$ Since then, Daesh have massacred countless civilians in both Iraq and Syria and further expansion had seen the fall of the provincial city Ramadi, the closest city to Baghdad, bringing Da'esh one step closer to the capital. ${ }^{6}$ However, the end of 2015 and the beginning of 2016 marked a significant loss of their controlled terrain in Iraq and Syria. In December 2015, they had lost control over more than 70 per cent of Ramadi and at the time of writing (July 2016) there is an ongoing military operation underway to liberate the city of Mosul from their control. In March 2016 they lost control of the ancient Syrian city of Palmyra and there are ongoing efforts by the us-backed Syria Democratic Forces (SDF) to retake al-Raqqa city.

International concern escalated in 2015 as the group progressed into Libya, capturing the city of Sirte, the Ghardabiya Air Base, Great Man-Made River water project and Nofilia though recent reports show that government forces have gained ground against Da'esh in Sirte. ${ }^{7}$ Libya gives the group cross-border access to Niger and Chad, both of which facilitate direct contact with its expanding Nigerian ally Boko Haram. ${ }^{8}$ Da'esh have also established them-

3 For an up-to-date information on Is's lost and controlled terrain in Iraq and Syria see recent IsIS sanctuary maps produced by the Institute of the Study War <http://www.understanding war.org >.

4 There are three principal components of the ISF: the Iraqi Army (IA), the Iraqi Police (IP), and the National Police (NP). The Iraqi Army and the National Police are both national-level assets, with the IA under the command of the Ministry of Defense and the NP under the command of the Ministry of Interior respectively. Conversely, the IP are recruited and deployed within local communities. See Institute for the Study of War, Iraqi Security Forces <http://www.un derstandingwar.org/iraqi-security-forces>.

5 unami Report on the Protection of Civilians in the Non-international Armed Conflict in Iraq 5 June-6July 2014 (UNAMI/ohCHR July 2014) <http://www.ohchr.org/Documents/Countries/IQ/ UNAMI_OHCHR_POC_Report_FINAL_6July_10September2014.pdf $>$.

6 OSC Report TRR2014111361251279, 'The "Islamic State" Crisis and U.S. policy' (Crs, May 27 2015) p1o (online) <http://mepoforum.sk/wp-content/uploads/2015/o6/R43612.pdf >.

7 S.A. Zway and D.D. Kirkpatrick, 'Western Officials Alarmed as IsIs Expands Territory in Libya' New York Times, (New York, 31 May 2015); See also Nicholas Norbrook, 'Libyan army gains ground against Is in Sirte' The Africa Report, (22 June 2016). <www.theafricareport.com/NorthAfrica/libyan-army-gains-ground-against-is-in-sirte.html $>$.

8 M. Scheuer, 'Islamic State is Winning, America Must Soon Use Its One Remaining Option' (Michael Scheuer's Non-Intervention.com, 8 August 2015) < www.non-intervention.com/1765/ islamic-state-is-winning-america-must-soon-use-its-one-remaining-option/>. 
selves strongly in the Islamist communities of Bosnia, Kosovo, and Albania, and have a presence in each of the other Balkan states. ${ }^{9}$ In addition, they have developed a presence in Afghanistan where they seek to increase their revenue streams through the country's heroin production and mineral wealth. ${ }^{10}$

Those who have fallen under Da'esh control are subjected to an extremely radicalised version of Islam (jihādi-Salafism) with a primitive interpretation of Shariah law being implemented throughout the controlled territory. The ideology of Da'esh also draws a great deal from the fundamentalist 18th century religious doctrine Wahhabiyya, founded by Muhammad Ibn 'Abd al-Wahhab (1703-1791). Even though the number of foreign fighters joining Da'esh has to some extent decreased, over the course of the whole war more than 40,000 citizens from 100 different countries have performed 'migration' (hijra) to join their ranks and defend the so-called 'Caliphate.11 According to the United Nations Assistance Mission in Iraq (UNAMI) 17,019 civilians have been killed in Iraq in 2014 at the hands of Da'esh who proceed to use the holy name of Islam to justify their barbaric actions. ${ }^{12}$ Consequently the UN Human Rights Council has requested the High Commissioner to 'dispatch a mission to Iraq to investigate alleged violations and abuses of international human rights law committed by ISIL and associated terrorist groups, and to establish the facts and circumstances of such abuses and violations, with a view to avoiding impunity and ensuring full accountability' ${ }^{\prime 3}$

9 Ibid.

10 Ibid. A report released in September 2015 by the House Committee on Homeland Security estimated that these numbers have only grown, with at least 25,000 foreign fighters travelling to join the Syrian conflict, including 250 Americans. See L. Curtis et al., 'Combating the ISIS Foreign Fighter Pipeline: A Global Approach', (Heritage Foundation, 6 January 2016) <www.heritage.org/research/reports/2016/o1/combatting-the-isis-foreign-fighterpipeline-a-global-approach $>$.

Congressional Research Service, C.M. Blanchard et al., "The "Islamic State" Crisis and U.S. Policy' (CRs Report Prepared for Members and Committee of Congress, 27 May 2015) $<$ www.mepoforum.sk/wp-content/uploads/2015/06/R43612.pdf> 'Is the Number of Foreign Fighters Joining IsIs Really Plummeting', World News (29 April 2016) < www.europe. newsweek.com/isis-foreign-fighters-9o-percent-iraq-syria-decreasing-general-claim453741 ? $\mathrm{rm}=\mathrm{eu}>$.

United Nations Assistance Mission for Iraq, Report on the Protection of Civilians in the NonInternational Armed Conflict in Iraq 11 September-10 December 2014 (UNAmi/ohCHR July 2014) I, (online) <www.ohchr.org/Documents/Countries/IQ/UNAMI_OHCHR_Sep_Dec_ 2014.pdf >. 
As the present article is concerned with the legitimacy of the group's resort to war, an in-depth analysis, of ius ad bellum from an Islamic law perspective is conducted in order to highlight the core justifications which form the Da'esh narrative with regard to waging war against their enemies. The article discusses the rise of the group before going on to assess their core rationale for waging war. This will then allow for a comparative analysis between the said rationale and the conditions permitting the resort to war under Islamic international law. The article will then discuss jihäd in light of its theological evolution, stripping it to its core to establish its traditional meaning before discussing it in light of its various guises. Is it a doctrine of expansionary nature, justifying war for the purpose of spreading Islam, eradicating barriers, expanding the Caliphate, and removing jahili (ignorant) forms of governance? Or is it strictly defensive, justifying recourse to war only when necessary to defend Muslim lands, protection from oppression and persecution? The results of this discussion shall provide an answer as to whether the dynamic modus operandi of Da'esh follows the requirements of defensive jihād and is therefore legitimate under Islamic law, or whether it is an illicit use of armed force closer in character to the crime of hiräbah (brigandage, banditry, highway robbery), most severely punishable under Islamic law. The article will demonstrate that conditions permitting the use of force are strictly regulated by the Qur'ann, the hadith (oral traditions attributed to the Prophet) and the Sunna (historical narratives typically about the Prophet but also his companions). The article provides evidence of deliberate distortions of Qur'ānic exegesis by Da'esh whilst aiding the evaluation of their legal status in light of ius ad bellum under Islamic international law.

\section{The Rise of Da'esh}

The radical ideological roots of Da'esh lie in the forces built and led by the late Abu Mus'ab al Zarqawi. ${ }^{14}$ The Jordanian thug-turned-terrorist created the group jama'at al-tawhid wal-jihäd (Monotheism and Jihäd) in 2003 which

<www.ohchr.org/EN/HRBodies/HRC/RegularSessions/Session28/Documents/A_ HRC_28_18_AUV.doc>. See also the recent report by the United Nations Human Rights Council, They Came to Destroy: IsIS Crimes Against the Yazidis (Un Doc. A/HRC/32/CRP.2, 15 June 2016). The Commission's report which focuses on violations committed in Syria has reached the following conclusion: 'IsIs has committed the crime of genocide as well as multiple crimes against humanity and war crimes against the Yazidis, thousands of whom are held captive in the Syrian Arab Republic where they are subjected to almost unimaginable horrors'. 
would soon go on to become Al-Qaeda in Iraq (AQI) (also known as Al-Qaeda in the land of the two rivers or Al-Qaeda in Mesopotamia) in 2004. ${ }^{15}$ Thriving on sectarian discrimination, the American invasion provided Zarqawi with an environment in which it was easy to instil his religious ideals and brutal tactics into Iraq's Sunni Muslims. ${ }^{16}$ After his death in 2006 an AQI spokesperson announced the creation of the Islamic State in Iraq (ISI) headed by Omar alBaghdadi as its Emir. The group's power began to diminish, due to a series of successful joint us-Iraqi counterterror strikes, two of which killed Al-Qaeda leader Abu Hamza al Muhajir and Abu Omar al-Baghdadi in 2010. ${ }^{17}$ With IsI's leadership in disarray, Dr Abu Bakr al Baghdadi (Ibrahim Awwad Al-Badri) ascended to lead the Islamic State in Iraq and the Levant (ISIL). Due to his education in Islamic law far exceeding that of Al-Qaeda leaders, Abu Bakr was perfectly suited for the position. ${ }^{18}$ Baghdadi's imprisonment at Camp Bucca enabled him to develop a network of trusted allies, ex-Ba'athist leaders, whom he would later use to rebuild the crumbled framework of IsI. ${ }^{19}$

The period between 2011 and 2013 evidenced the rise of the Islamic State in Iraq and the Levant (ISIL) as the group consolidated its military control and financial capacity in north-eastern Syria. ${ }^{20}$ On the 9th April 2013, Baghdadi announced the merger of ISIL and Jabhat Al Nusra, establishing himself as the leader of both organisations. By the end of 2013, he turned his attention back to Iraq, and began conducting dozens of deadly attacks by exploiting the political downfall and the sectarian divide. The brutality of the attacks combined with Baghdadi's reluctance to pledge allegiance to Al-Qaeda led to the latter formally disavowing ISIL on 2 February $2014 .{ }^{21}$ From this point onwards

15 G. Michael, 'The Legend and Legacy of Abu Musab al-Zarqawi (2007) 7 Defence Studies 338 , 357. See also H. Solomon, Islamic State and the Coming Global Confrontation (Palgrave Macmillan 2016) 1-5.

16 For more on the history of religious segregation between Sunni and Shi'a Muslims in Iraq see A. Hashim, 'Insurgency in Iraq', in P.B. Rich and I. Duyvesteyn (eds), The Routledge Handbook of Insurgency and Counter-Insurgency (Routledge 2012) 172-82.

M.J. Kirdar, 'Al Qaeda In Iraq' (Centre for Strategic and International Studies, 15 June 2011) $5<$ www.csis.org/analysis/al-qaeda-iraq> .

18 J. Stern and J.M. Berger, IsIs: The State of Terror (1st edn William Collins 2015) 37; Solomon (n 15) 5-10.

$19 \quad$ Ibid. 37.

20 United Nations Human Rights Council Report of the Independent International Commission of Inquiry on the Syrian Arab Republic (A/HRC/27/CRP.3) (19 November 2014) $2<$ www. ohchr.org/EN/HRBodies/HRC/IICISyria/Pages/IndependentInternationalCommission. aspx> . 
ISIL continued to advance in both Iraq and Syria making territorial gains before capturing Mosul in early June, a city of 1.5 million people and Iraq's largest dam. ${ }^{22}$

On 29 June 2014 Dr Abu Bakr al-Baghdadi emerged from the shadows to lead prayers at the great mosque in Mosul. Dressed in black, he presented himself as the heir to the Abbasid Caliphate as well as the embodied spirit of his heroic predecessor, Abu Mus'ab al-Zarqawi. ${ }^{23}$ The official spokesperson and senior leader of Da'esh, Abu Muhammad Al-'Adnani ash-Shami (killed in Aleppo on August 2016) collectively addressed the Muslim community (ummah) and the rest of the world announcing the formation of an 'Islamic Caliphate' with Abu Bakr Al-Baghdadi being named Caliph (Amir alMu'minin or the Commander of the Faithful). ${ }^{24}$

The self-declaration of the so-called Caliphate claims to unite the executive, legislative and judicial functions of Allah whilst claiming religious authority over all Muslims worldwide. Its creation had formed an integral part of the group's rhetorical and military expansionist aims since the outset of their activities. ${ }^{25}$ The proclaimed Caliphate implied that there was now a unified and single Islamic ecosystem, with its own currency and army and that 'all borders and barriers among Islamic countries are now invalid'. ${ }^{26}$

At the time of writing, Da'esh have claimed the establishment of, and control over, new provinces (wilayats) in Egypt, Saudi Arabia, Yemen, Afghanistan/Pakistan, Libya, Algeria, West Africa and the Caucasus region of Russia. ${ }^{27}$

Institute, 4 February 2014) <www.washingtoninstitute.org/policy-analysis/view/al-qaedadisaffiliates-with-the-islamic-state-of-iraq-and-al-sham >.

L. Sly and A. Ramadan, 'Insurgents Seize Iraqi City of Mosul as security forces flee' The Washington Post (June 10, 2014).

M. Weiss and H. Hassan, IsIs: Inside the Army of Terror (1st edn, Regan Arts 2015) 1. See also Solomon (n 15) 5-6.

24 'The Return of Khilafa' (Dabiq, issue 1, Ramadan 1435) $7<$ www.clarionproject.org/news/ islamic-state-isis-isil-propaganda-magazine-dabiq>; G. Wood, 'What IsIs's Leader Really Wants, The longer he lives, the more powerful he becomes' (New Republic, 1 September 2014) <www.newrepublic.com/article/119259/isis-history-islamic-states-new-caliphatesyria-and-iraq>

Human Rights Council, Report of the Independent International Commission of Inquiry on the Syrian Arab Republic. Rule of Terror: Living under ISIS in Syria (A/HRC/27/CRP. 3, 19 November 2014) 3 .

26 R. Mortada, 'What does IsIs' Declaration of a Caliphate Mean?' (Al-Akhbar English, 30 June 2014) <www.english.al-akhbar.com/node/20378> (n 15) 3 . 
In addition to this, Nigerian based Boko Haram ${ }^{28}$ and Ansar Bayt al-Maqdis in Northern Sinai have morphed into Da'esh-affiliated armed movements after pledging allegiance to the group in March 2015 and November 2014, rebranding themselves as the Islamic State in West Africa and wilayat Sinia respectively. ${ }^{29}$

An audio message released by Abu Bakr al-Baghdadi, in May 2015 calling 'all Muslims [to] go to war everywhere; It is the duty of every Muslim' reiterated the fear that Da'esh continues to present a global threat. ${ }^{30}$ The message further confirmed that Abu Bakr still enjoyed support from the group in his role as Caliph and put to rest claims that he had been incapacitated during recent bombings and thereby had lost the legitimacy required for such a position. ${ }^{31}$ The call continues to persuade individuals all over the world and the group has thus recently claimed responsibility for terrorist attacks in the United States, Tunisia, France, Australia, Germany, Belgium, Kuwait, Saudi Arabia and Egypt. A major factor in the power of the group is the far-reaching ability of its members and agents advanced and sustained social media propaganda. The use of religious doctrine and verses of the Qur'an combined with modern day lexis, resonates with group's vulnerable followers who are led to believe the atrocities committed by Da'esh and their declaration of jihäd are 'just' in the eyes of Islam. The catastrophic effect of this saw a shadow of devastation cast over Europe and indeed, the international community as a whole, on 13 November 2015 when 129 innocent civilians were killed in the city of Paris at the hands of Da'esh affiliates. Simultaneous attacks saw gunmen and suicide bombers hit the Bataclan concert hall, three restaurants/bars

tional Centre for Counter-Terrorism Research Paper, March 2016) <www.icct.nl/wp-con tent/uploads/2016/03/ICCT-Gartenstein-Ross-Is-Global-Propaganda-Strategy-March 2016.pdf>. See also CRs Report (n 11), 1.

28 For more information on Boko Haram's ideology and their practices see M.E. Badar et al. 'The International Criminal Court and the Nigerian Crisis, An Inquiry into Boko Haram Ideology and Practices from an Islamic Law Perspective' (2014) 3 International Human Rights Law Review 29.

29 On and around November 2014 several jihādist armed groups from Algeria, Egypt, Libya, Saudi Arabia, and Yemen have pledged bay'at (allegiance) to Is. In October 2014, in Yemen, a militant group named Supporters of the Caliphate in the Arabian Peninsula has also pledged bay'at to Baghdadi. "Islamic State releases 'al-Baghdadi message" BBC (London, 14 May 2014) <www.bbc.co.uk/ news/world-middle-east-32744070>.

31 'The rightful Caliph must be Muslim, fully grown, devout, sane, and physically whole. Because he is theoretically meant to lead Muslims in battle, missing limbs or a sickly disposition will automatically disqualify him. He must also hail from the Quraysh tribe of the Arabian peninsula' see Wood (n 24). 
as well as the Stade de France, where French president Francois Hollande was attending an international football game. ${ }^{32}$ The terrorist attack, conducted by three co-ordinated teams is the deadliest to hit Europe since the 2004 Madrid bombings. ${ }^{33}$

\section{Da'esh Use of Social Media as War Propaganda}

The rapid development in technology, mass media and global communication has enabled Da'esh to merge archaic religious references with modern tools. The group pushes its narrative through a number of media ranging from the internet, broadcast, traditional publications to video recordings in public parks and squares. In June 2014 Da'esh started the al-Bayān radio station in Mosul, which has been broadcasting readings of the Quran, lectures, and battlefield updates. The group also control several TV stations in Iraq and Syria. In addition to this, Da'esh began circulating a publication written in English called Islamic State News (and later Islamic State Report), which glorified their initiative through descriptions of their battles and key policies. The publications were brief and relied on graphics to magnify the narrative of Da'esh. However in early July 2014 (Ramadan $1435 \mathrm{AH}$ ), the first issue of Dābiq was released; a glossy in-depth propaganda magazine with unprecedented digital reach. ${ }^{34}$ This has enabled Da'esh to revive the appeal of jihäd forming a severely effective recruitment tool. In the second propaganda publication: 'The Flood', the metaphor of the story of Noah is used to put across a stark message: you are either with the Da'esh or against them and doomed to be destroyed. It calls on all Muslims around the world to pledge loyalty to the group and to move to their 'so called Caliphate' immediately. ${ }^{35}$ This pro-

32 'Paris attacks: What happened?' $в$ вв (London, 9 December 2015) <www.bbc.co.uk/news/ world-europe-34818994>.

33 On 14 July 2016, another deadliest attack shocked France where a terrorist used a truck to run over people celebrating the 2016 Bastille Day in Nice, leaving 84 dead and 308 injured. Is has claimed responsibility of the attack. <www.theguardian.com/world/live/2016/ jul/14/nice-bastille-day-france-attack-promenade-des-anglais-vehicle>. On 26 July 2016, two terrorists attacked a church in Normandy, France killing a 86-year old priest. Is has claimed responsibility of the attack. <www.theguardian.com/world/2016/jul/26/franceshock-second-isis-attack-12-days >.

34 M.E. Badar, "The Road to Genocide: The Propaganda Machine of the Self-Declared Islamic State' (2016) 16 International Criminal Law Review 361, 367-368.

'The Flood' (Dabiq, issue 2, Ramadan 1435) $20<$ www.clarionproject.org/news/islamicstate-isis-isil-propaganda-magazine-dabiq > 
nouncement put forward by Da'esh is almost completely dependent on an apocalyptic worldview. This interpretation is formed upon the idea that there has been a continuous downslide in society since after the time of the Prophet Muhammad and until the present day. ${ }^{36}$ As a result, Da'esh militants view themselves as the righteous avengers of the honour of Islam, burdened with the obligation to purify society by creating a just State. This radical ideology was instilled into the roots of Da'esh and it continues to inform their vision of jih $\bar{a} d$ and its obligatory nature. The late Abu Mus'ab al-Zarqawi warned the followers of the consequences of abandoning such a duty:

O nation of Islam, come to the rescue of the jihād in Iraq before the infidel majority besieges the mujahidin. $\mathrm{O}$ by God, who holds my soul, if the torch of jihād is extinguished, if the breath of jihād weakens, and if the pockets of jihād in Iraq are closed, the Islamic nation will not rise until God wills it to rise. The noose around the entire nation will be tightened and humiliation and submission will be forced upon the nation. It will then receive God's punishment. Then our conditions will be an embodiment of what Ibn Kathir said in his book, al-Bidaya wa al-nihaya [The Beginning and the End], namely, that when people abandoned jihād they were surprised to find the Tatars at their homes. A Tatar woman would pass by groups of men. She would tell them: 'Stop, do not go.' Then she would bring a knife and slay them all, one by one. They never showed any resistance. Thus the punishment will be followed by further punishments and the disobedience is followed by further disobedience. The punishment will not be lifted unless by full repentance. Repentance means a return to your religion, namely, jihâd. ${ }^{37}$

One can see here the central role played by the concept of jihād in the ideology and the military agenda of the movement, quite like in the case of Al-Qaeda. ${ }^{38}$ In the ninth issue of Da'esh propaganda magazine titled 'They Plot and Allah Plots', one can thus find the term jihâd referred to a total of 57

36 D. Cook, 'Fighting to Create the Just State, Apocalypticism in Radical Muslim Discourse' in S.H. Hashmi (ed), Just War, Holy Wars, and Jihäds - Christian, Jewish and Muslim Encounters and Exchanges (OUP 2012) 364-382.

37 Quoted Ibid. 375.

38 A. Guellali, 'Understanding the Discourses on Jihad in Islam Through Classical and Modern Narratives' in M.C. Bassiouni and A. Guellali (eds), Jihad and Its Challenges to International and Domestic Law (The Hague Academic Press 2010) 81. 
times. ${ }^{39}$ The same issue illustrates the life-cycle of jihäd and the steps to be followed by every jihadist joining the group:

One first performs hijrah to the lands of jihād (now, dārul-Isläm), then gives bay'ah, pledging what it entails of obedience (sam 'and tä́ah) to the amīr (now, the Khalifah) and commitment to the jamā'ah (now, the Khiläfah), then trains (ídād) for the purpose of jihäd, then patiently spends months of ribat [defending the frontiers posts], serves countless hours of guard duty (hirāsah), then fights (qitäl) in battles and kills (qatl) whom he can from amongst the käfir enemy, and finally achieves shahadah. ${ }^{40}$

The above quotation exhibits the Da'esh view that religion is almost entirely a project of social engineering combined with a rigid obedientialism, thus reducing it to a totalitarian system with excessive emphasis on outward conformity and a vision of every believer as a soldier. ${ }^{41}$ Apparently, the synonymous use of jihād with qital (fighting) and qatl (killing), combined with explicit use of an archaic lexis is a direct attempt to religiously justify the reduction of Islam to military action. ${ }^{42}$ This group's ultimate justification of waging war is jihād, encapsulated within this is a Muslim's duty to perform hijrah, pledge allegiance to Abu Bakr al-Baghdadi, guard the frontiers of the self-proclaimed Is (ribat) and then kill (qatl) the kafir (infidel) enemy, all of which is supplemented by the acknowledgement of achieving Shahadah (the basic statement of the Islamic faith). This, according to the Grand Mufti of Egypt, 'directly violates the cornerstones of the Islamic belief system that is built upon pillars of guidance not compulsion, moderation not extremism, peace not war, gentleness not harshness, love not hate; ease not hardship, cooperation not disassociation, brotherhood and sisterhood not enmity. ${ }^{43}$

39 'They Plot and Allah Plots' (Dabiq, issue 9, Sha'ban 1436) < www.clarionproject.org/news/ islamic-state-isis-isil-propaganda-magazine-dabiq>.

$40 \quad$ Ibid. 13.

41 C. Dagli, 'Jihād and the Islamic Law of War', in Ghazi bin Muhammad et al. (eds), War and Peace in Islam: The Uses and Abuses of Jihād (The Royal Islamic Strategic Studies Centre, 2013) 56-98 at 91 .

D. Dakake, 'The Myth of a Militant Islam' in Ghazi bin Muhammad et al. (eds), Ibid. 99-131 at 100 .

43 Dr S. Allam/The Grand Mufti of Egypt, 'The Ideological Battlefield: Egypt's Dar al-Iftaa Combats Radicalization', (The Egyptian Grant Mufti Office, 2015) < www.counterideology2. wordpress.com/2015/01/28/just-sharing-the-ideological-battlefield-egypts-dar-al-iftaacombats-radicalization/>. 
The Grand Mufti of Saudi Arabia in turn declared Da'esh as 'the number one enemy of Islam' which also reflects the split between original Wahhabism from which Da'esh draw their inspiration and the reformed Wahhabism of today.

\section{Da'esh Justifications for Waging War}

Da'esh believe that the 'world today has been divided into two camps', and that there is 'no third camp present'. ${ }^{4}$ To those considering following Da'esh beliefs it appears to leave no choice but to fully engage with their project or otherwise be considered the enemy. The two camps are depicted as 'Islam and faith and the camp of the "disbelief" (kufr) and hypocrisy'. 45 The self-proclaimed is embodies its struggle to purify Islam as a legitimate act under the banner of jihād. The religious claim of legitimacy is the crux of a sustained and rallying narrative that has enabled Da'esh to recruit thousands of fighters to join their ranks. The justifications put forth by Da'esh for waging war against not just the West, but any state, society and individual who objects to their primitive interpretation of Islam, span across a three tiered spectrum, namely, ideological, political and militant. The ideological and militant justifications form the foundations to support the political, each providing an individual justification yet all equally reliant on each other when conducting an analysis of their legitimacy.

The political justification for waging war forms the ultimate objective of Da'esh narrative; to establish and expand a 'Caliphate' (Khiläfa) until the parameters of the world fall under the banner of Islam. ${ }^{46}$ Territorial expansion, in order to extend an Islamic form of governance which strictly abides by their distorted version of Shari'ah was the fundamental goal of Da'esh since its inception and remains so today. ${ }^{47}$ Leaders of this group stipulate that, as a definite ruling of Islam, Muslims fall under an obligatory duty to unite in one body, appoint a single leader, and obey him, proof of which is in the Shariah. ${ }^{48}$ As such, Da'esh believe that the appointment of al-Baghdadi as Caliph and

\footnotetext{
44 'The Return of the Khilafah' (Dabiq, issue 1, Ramadan 1435 AH) 10-11 < www.clarionproject .org/news/islamic-state-isis-isil-propaganda-magazine-dabiq>.

45 Ibid. 11.

46 Ibid. 34 .

47 Ibid. 8 .

48 'From the Battle of Al-Ahzab to the War of Coalitions' (Dabiq, issue 11, Dhul-Qa'dah 1436) $10<$ www.clarionproject.org/news/islamic-state-isis-isil-propaganda-magazine-dabiq $>$.
} 
the declaration of a Caliphate is in accordance with the tenets of Islam, making territorial expansion a legitimate means for waging war.

The political becomes intertwined with the ideological in a second justification put forth by Daesh; the expansion of a Caliphate is fundamental as Islamic countries such as Iraq and Syria are governed by regimes which have fallen into 'ignorance' (jahiliyya) and have broken the postulates of the Shariah. This stems from the Salafi doctrine which stipulates that a State should be governed in accordance with 'God's oneness' (tawhid), recognising 'God's sovereignty' (hakimiyya) as the only legitimate form of governance. Da'esh leaders argue that, as Muslim States have become modernised, corrupt and subject to Western influence, they have deviated away from the true path of Islam. ${ }^{49}$ As such, it is the collective duty of Da'esh to expand the Caliphate and revise Islam to reform the jahili society. ${ }^{50}$

Within this ideological context lies the practice of excommunication (takfir), which literally means: 'declaring somebody - who, in this case, is an actual member of the [Muslim] community and passes for a believer - to be a Kāfir, and condemning him as such' and should be lawfully killed. ${ }^{51}$ As a result, the Da'esh continues to wage war, not just to expand their so-called Caliphate and overthrow jahilli governments, but to convert or eradicate non-Muslims as well as Muslims within their control who object to their distorted view of the correct application of Islam. This ideological justification is further enhanced through the Sunni/Shi'a sectarian divide. Eradicating Shi'a forms one of the major reasons for Da'esh atrocities. The divide between the Sunni and Shi'a has long been a part of Islamic history. However, in relation to modern times, ever since the Us invasion of Iraq in 2003, this hatred has spearheaded militant groups' narrative for waging war. ${ }^{52}$ Replacing Saddam Hussein's Sunni majority government with Nouri Al Maliki's Shi'a majority acted as a catalyst for sectarianism, pushing 85,000 Iraqi civil servants into unemployment and demobilising 400,00o Iraqi armed forces. Indeed, the hatred Da'esh has shown towards Shi'a Muslims has reached genocidal proportions, as their eradication becomes a key target in the strategy. ${ }^{53}$

49 Ibid. 6.

$50 \quad$ 'The Return of the Khilafah' (n 44) 35 .

$5_{1}$ T. Izutsu, The Concept of Belief in Islamic Theology: A Semantic Analysis of Iman and Islam, (Yurindo Publishing, 1965) 11. For more on the meaning, conception and practice of Takfir see C. Adang et al. (eds), Accusations of Unbelief in Islam: A Diachronic Perspective on Takfir (Brill 2015).

$5^{2}$ 'From the Battle of Al-Ahzab to the War of Coalitions' (n 48) 16.

53 See Badar, 'The Road to Genocide' (n 34) 401-9. 
The militant aspect of Da'esh declarations of war comes in the form of an offensively defensive jih $\bar{a} d$. The group leaders believe themselves to be engaged in a war with Western and Coalition led forces and are responding as a matter of self-defence. ${ }^{54}$ It is significant in this regard to note that notion of jihād is influenced by the writings of Taqi al-Din Ahmad Ibn Taymiyya (also known as Sheykh al Islam) a prominent Muslim scholar who was born immediately after the fall of the Abbasid Caliphate at the hands of the Mongol forces in the year $656 \mathrm{AH} / 1258 \mathrm{CE}$. His famous fatwa that applied for the first time the concept of jihād as an authorisation to fight the Muslim ruler who abandoned Islam through his disbelief and his disregard for Shari'ah has had a significant influence on extremist militant groups who have been declaring jihād against their governments. Ibn Taymiyyah considered that jihād must be waged against all those who stand against the triumph of God's will on earth:'[s]ince lawful warfare is essentially jihād and since its aim is that religion is God's entirely and God's word is uppermost, therefore according to all Muslims, those who stand in the way of this aim must be fought'. ${ }^{55}$

This line of reasoning has formed the basis of Da'esh justification for its actions and the claim that this group's jihād is lawful under Shariah. ${ }^{56}$ Whether these justifications are grounded in, or supported by, Islamic international law is the focus of the subsequent sections.

\section{Islamic International Law (Siyar)}

In the second century of the Islamic era, the term siyar was used by jurists to refer to the conduct of the government of the ummah in its relationship with other communities. ${ }^{57}$ In the Sunna, the word siyar is used to refer to the military expeditions and missionary journeys sent by the Prophet. ${ }^{58}$ In the

54 'From the Battle of Al-Ahzab to the War of Coalitions' (n 48) 46.

55 A. Ibn Taymiyya, al-Siyāsa al-Shar'iyya fi Islah al-ra'i wa al-ra'iyya, (Dar al-Arqam, $1406 \mathrm{AH}$, 1986 AD) quoted in R. Peters, Jihad in Classical and Modern Islam: A Reader (2nd edn, Markus Wiener Publishers 2009) 44.

$5^{6} \quad$ 'The Return of the Khilafah' (n 44) 34.

57 M. Khadduri (trs), The Islamic Law of Nations: Shaybānìs Siyar (John Hopkins University Press 1966) 39. For the early terminology and usage of the term Siyar see M. Hamidullah, Muslim Conduct of State (4th edn. Sh. Muhammad Ashraf 1961) 10: 'When Islam came and founded a State of its own, the earliest name given by Muslim writers to the special branch of law dealing with war, peace and neutrality seems to have been Siyar, the plural form of Sirat, meaning conduct and behaviour'.

$5^{8}$ A.I. Bouzenita, 'The Siyar - An Islamic of Nations?' (2007) 35 Asian Journal of Social Science 19, 20; A. Al-Dawoody, The Islamic Law of War:Justifications and Regulations (Palgrave McMillan 2011) 109 . 
legal context, the word refers to the areas of Islamic international and Islamic humanitarian law; thus 'to the ways and methods followed by the Prophet in his dealings with non-Muslim states and individuals in times of peace and war'.59 Subsequently, the aim of the jurists expanding on the notion after the death of the Prophet was to regulate the conduct of the Islamic State with regard to non-Muslim states, in accordance with the rules of the Qur'ann and the precedents laid down by the Prophet. ${ }^{60}$

At the broadest level, there are foundational differences between international law and siyar. The former is derived from a mixture of natural law and positive law in the form of inter-state treaties and implied agreement, while the latter is derived from divine law, documented by the Qur'ān and the hadith. However, as Mahdi Zahraa points out siyar 'is not ab initio representative of Islamic law, but rather is a collection of views and opinions that should be assessed in the light of the Qur'ann, the Sunna and the contingencies of time and place.' ${ }^{61}$ The opinions of early Muslim jurists do not represent a comprehensive theory of international law for the modern age and so it has been left to current jurists to develop the teachings of the Qur'än into a workable model. Classical siyar saw the world as essentially divided into dār al-Islam (abode of peace) and dār al-harb (abode of war), and in the expansionist era of Islamic history, those within the dār al-Islam did not recognise the equality of states residing outside the Muslim ummah. ${ }^{62}$ The imagery of these two abodes soon allowed for 'the legitimisation of violence against the

$59 \quad$ Ibid. 109.

6o Ibid. See also M. Khadduri, War and Peace in Islam (The John Hopkins Press 1955) 47; M.T. Al Ghunaimi, The Muslim Conception of International Law and the Western Approach (Martinus Nijhoff 1968) 96; Khadduri (n 57), 39; N.A. Shah, Islamic Law and the Law of Armed Conflict: The Armed Conflict in Pakistan (Routledge 2011) 6o-69; R. Moschtaghi, 'The Relations between International Law, Islamic Law and Constitutional Law of the Islamic Republic of Iran - A Multilayer System of Conflict?' (2009) 13 Max Planck Yearbook of United Nations Law 375, 392. According to Khadduri (n 57) 19: 'The classical theory of the Islamic law of nations is found neither in the Qur'ān nor in the prophet's utterances, although its basic assumptions were derived from these authoritative sources; it was rather the product of Islamic juridical speculation at the height of the Islamic power'.

61 M. Zahraa, 'Characteristic Features of Islamic Law: Perceptions and Misconceptions' (2000) 15 Arab Law Quarterly 191.

$62 \quad$ Al Ghunaimi (n 6o) $155^{-5} 6$ noting that Muslims jurists 'did not come to agreement about what is dar al-Islam and what is dar al-harb... Hanafists, provide that territory must be either Muslim or harbi since they do not accept that a given territory may stay outside the pale of the Islamic conquest... Al-Shafi'i advocated a third division of the world, viz. dar al-sulh, world of peace, or dar al muwad'ah or al'ahd, world of covenant'. 
others, those who belong to the territory of Harb, of war. ${ }^{63}$ The earliest jurists from the 7th century, who belonged to the Hanafi school, were of the position that non-believers could only be fought if they resorted to armed conflict and not simply on account of their disbelief. ${ }^{64}$ Already in the 8th century, however, this changed with the advent of the Syrian School of thought which reflected the reality of Syrian Umayyads fighting with Byzantines. ${ }^{65}$ They saw aggressive war to overcome the dār al-harb not merely as permissible but as 'a moral obligation ... for those capable of assuming it, namely able-bodied and financially secure adult males.' 66

It is important to understand, however, that the division between the two abodes is not as simple as equating dār al-Islam with Muslim territory and $d \bar{a} r$ al-harb with the territory under the control of the unbelievers. According to Abu Hanifa, even non-Muslim territory can be part of dār al-Islam as long as a truce has been concluded with the Muslims and tribute is paid to them for protection. ${ }^{67}$ On the other hand, Muslim territory can be transformed into dār al-harb if the state applies the law of non-Muslims or the security of Muslims and the protected people among the non-Muslims 'the dhimmah - people of the book' is compromised. ${ }^{68} \mathrm{Abu}$ Yusuf and al-Shaybānī, both followers of the Hanafì school, reassert the first condition as sufficient to transform dār alIslam into a dār al-harb. ${ }^{69}$ In other words, if Muslim territory 'applied the law of unbelievers it will become a territory of unbelief even if most of the inhabitants are Muslims. ${ }^{70}$ Furthermore, even if Islamic law is applied in Muslim territory, but those governing it are non-Muslims, it will remain a dār al-harb, according to other jurists from the Hanafi school, as the power should be in the hands of Muslims. ${ }^{71}$

\footnotetext{
63 Guellali (n 38$) 71$.

64 A. Afsaruddin, 'Views of Jihad throughout History', (2007) 1 Religion Compass 165, 167.

65 Ibid.

66 S.H. Hashmi, 'Jihad' in R. Wuthnow (ed), Encyclopedia of Politics and Religion (Routledge 1998) 425-26.

$67 \quad$ Afsaruddin (n 64).

68 A. Bakr Al-Kāssānī, Badāi' al-Sanai' fi Tarteeb al-Sharāi (vol. 7 Dār al-Kutub al-'Ilmiyya, 1406 AH) 130; M. Al-Butī, al-jihāa fi al-Islām (Dār al-Fikr, 1412 AH, 1991 AD) 198; R. Peters, Islam and Colonialism, The Doctrine of Jihad in Modern History (Mouton Publisher 1979) 12; M.K. Haykal, al Jihād wa al-Qitāl fi al-Siyāsa al-Shar'iyya (vol. 1 Dār al-Bayāriq, 1414 AH, 1993 AD) 662.

69 Haykal, Ibid. 662; Peters, Ibid, 12.

70 Haykal (n 68) 662; Peters (n 68)12.

71 Ibid.
} 
Al-Shafi'i added to the two abodes a third division of the world, i.e. dār alsulh, world of peace, or dār al muwad'ah or al'ahd, abode of covenant. ${ }^{72}$ By doing so, he no longer allowed for the option of non-Muslim territory to be considered as dār al-Islam. Those who entered a treaty with the Muslims and paid tribute to them, were now considered to fall under this third abode of temporary peace. It was not until the 12th century that dār al-Islam was again perceived more broadly, to include non-Muslim territory where Muslims were free to practice their religion. ${ }^{73}$ In the same way as the original Wahhabis before them, Da'esh however, considers only lands under its control as dār al-Islam. Both ideologies encourage hijra to said lands and then command the expansion of their rule unlimited by geographical borders with the rules being imam to all Muslims in contrast to the reformed Wahhabism which rejects the idea of Caliphate and expansive jihād. ${ }^{74}$

It is important to note, that the Islamic world has not refused to integrate into the modern international law system in more recent history. All Muslim majority States are members of the United Nations and all are signatories of the Geneva Conventions. As noted by Javaid Rehman, they all 'have accepted the provisions of Article 2(4) of the United Nations Charter. There is also a renunciation of violence, aggression and terrorism. They have adopted this position without renouncing their Islamic credentials. ${ }^{75}$ Thus siyar had evolved to allow for permanent non-violent legal contact with non-Muslim political entities in the form of treaty-making and diplomacy. This evolution is perceived by Da'esh as the corrupt modernisation of Islam. However, such development did not merely arise out of political and economic necessity, but is arguably a more authentic siyar, one which is closer to the teachings of the Qur'àn and the Sunna, than the concept of dividing the world into där alIslam and dār al-harb.

When it comes to ius ad bellum, we can distinguish two paths which siyar has taken. The first one refers to the right to a defensive jiha a d. In this sense, the concepts embodied in the siyar have presented a continuum from the days of the Prophet until today, when it is still regularly invoked, especially in the relationships between Muslim states. ${ }^{76} \mathrm{~A}$ similar continuity can be

\footnotetext{
$72 \quad$ Al Ghunaimi (n 6o) $155^{-56 .}$

73 Afsaruddin (n 64) 167-8.

74 B. Al-Ibrahim, 'IsIs, Wahhabism and Takfir' (2015) 8 Contemporary Arab Affairs 408, 412.

75 J. Rehman, Islamic State Practices, International Law and the Threat from Terrorism: A Critique of the 'Clash of Civilizations' in the New World Order (Hart Publishing 2005) 60.

${ }_{7} 6$ S.H. Hashmi, 'Jihād and the Geneva Conventions: the Impact of International Law on Islamic Theory' in S.H. Hashmi (ed), Just War, Holy Wars, and Jihäds - Christian, Jewish and Muslim Encounters and Exchanges (OuP 2012) 332.
} 
found in terms of ius in bello, i.e. Islamic humanitarian law. It is only in the sense of offensive war, that siyar had diverted from the strict teachings of the Qur'an and Sunna in the centuries after the death of the Prophet, and has only recently been rightly reformed to fit with Islam's original message, as well as the modern international status quo. As mentioned previously, groups such as Da'esh, refuse this reformation and prefer to stick to the aggressive version. In this sense they mirror the Ikhwan man ta'a Allah, a radical group created by Ibn Saud, the founder of the modern state of Saudi Arabia. Ibn Saud used their fanaticism for the conquests of his rivals in the region, i.e. the Rashids backed by the Turks and the Sharifs of Hejaz, however when he wished to discontinue expansive jiha $\bar{d}$ to adhere to the international order, the Ikhwan refused to abandon the original Wahhabi ideology which he himself had taught them and which declared all non-Wahhabi Muslims as infidels. ${ }^{77}$ They thus declared him a traitor and continued with invasions against his wishes until he crushed them at the battle of Sibilla. ${ }^{78}$

Muslim religious concepts have undergone a similar process in the crystallisation of what is ius ad bellum as had taken place in the 'western' domestic and international law. This is despite the fact that secularism, which has played an important role in the latter, has never fully established itself in Muslim majority countries. The doctrine of 'just war', in itself a pre-Christian concept which was adapted in medieval Christian thought through the theological exercises of Aquinas and Augustine, constitutes one of the most important influences of the Christian religion on international ius ad bellum in how it severely restricted the reasons to go to war. ${ }^{79}$ At the same time, holy war with concepts such as the right to fight heretics and infidels to spread the faith, or the condemnation of treaties with Muslims, motivated by the desire to unite the Christian world under papal authority, also formed part of the Christian approach to war and it took secularisation, started by Gentili and Grotius and subsequently continued by writers like de Vattel, to discard it in their 'just war' theories. ${ }^{80}$.

Given the fact that many in Muslim majority countries still sceptically look upon secularism and that Muslims will always put God's law first, it is

\footnotetext{
$77 \quad$ Al-Ibrahim (n 74) 409 .

78 Ibid.

79 A. von Ungern-Sternberg, 'Religion and Religious Intervention' in B. Fassbender and A. Peters (eds), The Oxford Handbook of The History of International Law (oup 2012) 302.

$80 \quad$ Ibid. 301, 303-304; See also Al-Dawoody (n 58) 109; Hammīdullāh (n 57) 3; Khadduri (n 6o) 47; Al Ghunaimi (n 6o) 96; Khadduri (n 57) 39; Shah (n 6o) 6o-69; Moschtaghi (n 6o) 392; Zahraa (n 61) 191.
} 
important to acknowledge the identity between international law norms and modern siyar on the matter of ius ad bellum if we are to expect lasting peace between Muslim and other nations, and groups.

\section{Illegitimate Use of Force for Establishing a Caliphate?}

According to classical Sunni doctrine, the universality of the Caliphate is the only religiously supported political form available to the Muslim world, and revolution against it is condemned. ${ }^{81}$ However in the 1oth and nth centuries $\mathrm{CE}$, the economic basis of the Islamic Caliphate began to erode and regional powers started to exercise virtually autonomous control over limited areas of the central Caliphate's domain. ${ }^{82}$ When they began to declare independence, the Sunni doctrine saw these claims as tantamount to heresy. ${ }^{83}$ However the trend toward decentralisation continued and was further reinforced by the Crusades and the Mongol invasions. ${ }^{84}$ In the $15^{\text {th }}$ and 16th centuries the Islamic world fell under Ottoman Turkish control and in their desire to once again encourage unity, the scholars gave the Ottoman ruler religious legitimation as the Caliph. ${ }^{85}$ However, after the fall of the Ottoman Empire, the region came under effective European control which eventually brought about the various nation-States of today. In the latter half of the 2othcentury the region has thus witnessed a struggle for independence, which as Tamara Sonn explains is:

in one sense, a part of the struggle of Muslims to be free from foreign domination that began in the thirteenth century. In another sense, the struggle is to come to grips with the historical phenomenon of decentralization in the Islamic world... [G]overnments... are struggling to establish their legitimacy within the context of a religious tradition that still conceives of politics in terms of the ideal of a universal Islamic state. The conflict is between social and economic realities that favour nation-states and a religious tradition that thinks of a single, centralised

81 T. Sonn, 'Irregular Warfare and Terrorism in Islam: Asking the Right Questions' in J.T. Johnson and J. Kelsay (eds), Cross, Crescent and Sword: The Justification and Limitation of War in Western Islamic Tradition (Greenwood Press 1990) 133-134. For more on the Islamic conception of 'state', 'ummah', 'jama'a', 'dawlah' see Al Ghunaimi (n 6o) 61-70. For more on the rise and fall of the Islamic Caliphate see N. Ardiç, Islam and Politics of Secularism: The Caliphate and Middle Eastern Modernization in the Early 2oth Century (Routledge 2012).

$82 \quad$ Sonn. Ibid. 131.

83 Ibid.

84 Ibid. 132.

85 Ibid. 
government for the entire region... These difficulties weaken the claims of existing governments to Islamic legitimacy; this invites criticism of the governments, which in turn breeds repressive responses. ${ }^{86}$

As mentioned, according to classical Sunni doctrine, there can be only one source of political legitimacy: religion, and since the latter is considered universal, there could only be one legitimate political power, namely the universal Caliphate, revolution against which is condemned. ${ }^{87}$ Other territorial rulers were accepted, as long as they were recognised by the Caliph, even if the relation was purely formal, in which case, according to al-Mawardi, even a usurper had to be obeyed, so long as he formally recognised the authority of the Caliph. 88

According to siyar, the declaration of war is generally entrusted to the highest responsible authority in the State, the Imam, and the ummah (Muslim community) has to obey him. This applies in situations of collective jihäd but when jihād is a personal duty, the foundation of Imām is not a sine qua non for the declaration of $j i h \bar{a} d .{ }^{89}$ There is also a consensus among the majority of Muslim jurists that 'Islam does not permit recourse to violence that disturbs peace and order in society even if it be against a government of questionable legitimacy so long as that government stays short of blatant indulgence in criminality and kufr (denial and rejection of Islam). ${ }^{90}$ In light of this, Da'esh jihādi rhetoric firstly declares that Abu Bakr al-Baghdadi, as appointed Caliph (Khalifah) is legitimate and as such, possesses authority over Muslims worldwide and the ability to declare war. In addition, extreme emphasis is placed on Muslims' duty to submit to the so-called Caliphate. According to the Da'esh propaganda magazine: ' $[\mathrm{t}]$ he Islamic State actively works to educate its citizens, preach to and admonish them, enforce their strict adherence to Islamic obligations [...] eradicate all traces of shirk and heresy, incite the people to jihād and call them to unite behind the Khalīfah. ${ }^{91}$ It is in the propaganda of radical groups that we find the complex relationship between the notion of a Caliphate and the utilisation of jihād to achieve it. Da'esh propaganda maga-

\footnotetext{
86 Ibid.

87 Ibid. $133^{-134}$.

88 Ibid. 134 .

89 Ibn Qudāma al-Maqdasi, al-Mughnī, (vol.8 Maktabat al-Qahira 1969) 352; 'Alī ibn Muhammad Al-Māwardī, al-Ahkām al-Sultāniyya (Dār al-Kutub al-'Ilmiyya, 1405 AH, 1985 AD) 5 .

go M.H. Kamali, 'Jiha $\bar{d}$ and the Interpretation of the Quran: Contextualising Islamic Tradition' in Bassiouni and Guellali (n 38), 57.

91 'A Call to Hijrah', (Dabiq, issue 3, Shawwal 1435 AH) 17 <www.clarionproject.org/news/ islamic-state-isis-isil-propaganda-magazine-dabiq >.
} 
zine, Dabiq, displays this while outlining the 'route to the Caliphate'. The five steps to Caliphate include: hijrah (emigration), jama'ah (congregation), destabilise taghut (idolatry), tamkin (consolidation), and khilafah (caliphate) as seen in the figure below. ${ }^{92}$

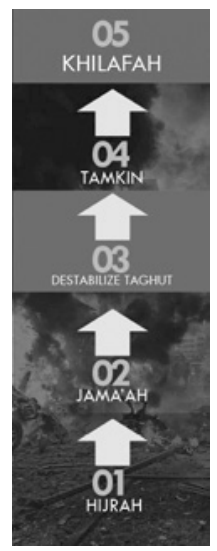

The plan is not only informative but demonstrates how Da'esh uses theoretical propaganda to justify its military action and therefore its superiority over other armed groups. The legitimacy of establishing a Caliphate hangs on the ability to produce military victory through jihād and consolidation of success, as proof of Allah's approval. Understanding this ratio is key to understanding both the practical and emotional relationship between jihād and the Caliphate. Indeed Daesh has gone as far as to undermine and criticise other radical groups, including Al-Qa'eda, who have failed in the overall and overarching Islamic duty to establish a Caliphate. ${ }^{93}$ Da'esh represents a zero sum ideology; either you are with this group in the establishment of an Islamic Caliphate or you are an infidel. Indeed by failing to adopt the radical ideology as propounded by Da'esh any leader of a Muslim-majority country is identified as deviant, and thus open to attack. ${ }^{94}$ However, by refusing to interact with any organisations that it considers impure, Da'esh has ensured that the only option available to them is one of military force, as diplomacy and working for mutual advantage is no longer an option.

\footnotetext{
92 H.K. Gamnhir, 'Dabiq: The Strategic Messaging of the Islamic State' (Institute for the Study of War, 15 August 2014) 8 <http://www.understandingwar.org/backgrounder/dabiq-strate gic-messaging-islamic-state $>$.

93 Ibid.

94 Ibid.
} 
However, the authenticity of al-Baghdadi's claim as the rightful Caliph of a legitimate self-proclaimed caliphate is fundamentally flawed. A letter addressed to al-Baghdadi, composed and signed by over a 100 leading Muslim scholars, identifies the illegitimacy of his self-declared 'Caliph' status and as such, his authority to wage jihād:

There is agreement (ittifaq) among scholars that a caliphate is an obligation upon the Ummah. A new caliphate requires consensus from all Muslims. Omar ibn Al-Khattab said: 'Whosoever pledges allegiance to a man without due consultation with Muslims has fooled himself; and neither he nor the man to whom he pledged allegiance should be followed for he has risked both their lives. In your speech, you quoted the Companion Abu Bakr Al-Siddiq: 'I have been given authority over you, and I am not the best of you.' This begs the question: who gave you authority over the ummah? Was it your group? If this is the case, then a group of no more than several thousand has appointed itself the ruler of over a 1.6 billion Muslims. This attitude is based upon a corrupt circular logic that says: 'Only we are Muslims, and we decide who the caliph is, we have chosen one and so whoever does not accept our caliph is not a Muslim.' In this case, a caliph is nothing more than the leader of a certain group that declares more than 99 per cent of Muslims non-Muslim. Thus, you face one of two conclusions: either you concur that they are Muslims and they did not appoint you caliph over them - in which case you are not the caliph - or, the other conclusion is that you do not accept them as Muslims, in which case Muslims are a small group not in need of a caliph, so why use the word 'caliph' at all? In truth, the caliphate must emerge from a consensus of Muslim countries, organizations of Islamic scholars and Muslims across the globe. ${ }^{95}$

Thus, the formation of a new Caliphate requires consensus from all Muslim countries, organisations of Islamic scholars and Muslims across the globe. ${ }^{96}$ This counterargument ultimately refutes the Da'esh claim to wage a global jihād in order to expand the Caliphate because the Caliphate itself has been illegitimately created. Islam rejects the postulate that the ends justify the

95 'Open Letter to Dr. Ibrahim Awwad Al-Badri, Alias "Abu Bakr Al-Baghdadi” and to the Fighters and Followers of the Self-Declared "Islamic State"' (19 September 2014) <www. lettertobaghdadi.com/pdf/Booklet-English.pdf>.

Ibid. 27 . 
means ${ }^{\prime 97}$ requiring that both the ends and the means conform to its values and principles and to its specific legal dictates. Therefore, violent conduct towards Muslim and non-Muslim civilians in order to achieve such a goal runs contrary to the very tenets of Islam. However, hypothetically speaking, if the Caliphate were legitimate, this, according to the majority of classical doctrine of jiha $\bar{d}$, would permit waging war in the name of territorial expansion. Moreover, the jurists of this period were of the view that Shari'ah required the head of state to organise yearly raids into enemy territory. ${ }^{98}$ These interpretations however have no basis in the Qur'ān or the Sunnah. Rather, much like the division of the world into dār al-Islam and dār al-harb, such ideas were based on ad hoc juristic interpretations of particularly the verses 9:5 and 9:29, in search of justifications of the realpolitik of the time and as such are not doctrinally binding in any way. ${ }^{99}$

\section{Da'esh and the Khārijites Conception of Jihād}

The barbaric actions of Da'esh may in fact be viewed as nothing more than history repeating itself. The characteristics of Da'esh and its conception of jihād bears a strong resemblance to those of the al-Muhakkimah, the first sect of the Khärijites. Due to the actions of this group and its fanaticism that sheds the blood of thousands of Muslims, the majority of Muslim scholars have specified them as Khärijites or Khawārij as meaning everyone who separated from the Muslim ummah. ${ }^{100}$ The term Khärijite is also known as khawārij or khäriji, and is derived from the verb kharaja meaning 'to come out, to exit.' During the period of the fourth Caliph $(656-661 \mathrm{CE})$, which coincided with the first Muslim civil war, Caliph 'Ali felt obliged to accept arbitration during the battle of Siffin. ${ }^{101} \mathrm{Al}$-Muhakkimah, who were considered to be among 'Ali's followers regarded all those who admitted the authority of human decision

97 M.C. Bassiouni, 'Misunderstanding Islam on the Use of Violence' (2015) 37 Houston Journal of International Law 648.

$98 \quad$ Peters (n 55) 112.

99 Afsaruddin (n 64) 167.

100 I. Goldhizer, Introduction to Islamic Theology and Law (Princeton University Press 1981) 1781. For further information on the Khārijites see J.T. Kenney, Muslim Rebels: Khārijites and the Politics of Extremism in Egypt (oup 2006) 21; Izutsu (n 51) 1-16 discussing the Khārijites concept of takfir; W.M. Watt, The Formative Period of Islamic Thought, (Oneworld Publications 1998); A.K. Kazi and J.G. Flynn (trs), Mohammad b. 'Abd al-Karim Shahrastini, Muslim Sects and Divisions (Kegan Paul International 1984); K.C. Seelye (trs), Abu-Mansur 'abd-al-Kahir ibn-Tahir al-Baghdadi, Moslem Schisms and Sects (Columbia University Press 1920).

101 Allam (n 43) 119-127. 
( hukm), in the present case, 'Ali and the two arbiters, as downright infidels. ${ }^{102}$ They claimed that there was no decision but God's (la hukm illa lillāh), which is based on the Quranic verse 5:47: 'Whoever does not judge by that which God has revealed, such surely are infidels'. Rebelling against 'Ali they declared him an unbeliever, accusing him of compromising God's sovereignty by judging on matters in which God is the only judge. ${ }^{103}$ It was arguably this decision that was the most prominent in the rise of the Khärijites.

The primary motivation of the Kharijites was to secure the kingdom of God on earth and as such, whoever did not rule in accordance with the rule of God was considered an infidel and was not to be obeyed. To achieve their goal they began exhibiting extremist tendencies, introducing acts of martyrdom and violent attacks against those Muslims who did not agree with their views. ${ }^{104}$ The latter were deemed as unbelievers and the Khärijites believed that jihäd against them was obligatory by whatever means suitable, no matter how extreme. ${ }^{105}$ Contrary to the mainstream Sunni doctrine, is argued that right belief was insufficient as a criterion to distinguish Muslims from non-Muslims and that right action was also required. ${ }^{106}$ In the same vein, the Khärijites believed that 'anyone who claimed to be a Muslim but committed forbidden acts forfeited that claim' and 'such a person could never re-enter Islam and should thus be killed along with his immediate family'.107 Through their focus on the Qur'ann and what they believed was the intention of the word of Allah they became assured of their own religious purity and set about creating an ideal community of the saved. ${ }^{108}$

The Khärijites, just like Da'esh, believed that jihād was a fundamental article of the Muslim faith and the sixth pillar of the Islamic religion. ${ }^{109}$ Jihäd is to be waged against those who did not accept their view of Islam, Muslims as well as non-Muslims. Muslim scholar Ibn Taymiya explained that they considered only their land as the dār al-Islam (abode of Islam/abode of peace) and all other land, including that of all other Muslims as the dār al-härb (abode of war). As a result of this, they regarded wasting Muslim lives and seizing

\footnotetext{
$102 \quad$ Izutsu (n 51$) 5$.

103 M.F. bin Mohd Sharif, 'Baghy in Islamic Law and the Thinking of Ibn Taymiyya' (2006) 20 Arab Law Quarterly 289, 301.

104 Kenney (n 100) 34-35.

105 J. Kelsay, Arguing the Just War in Islam (Harvard University Press 2007) 119-120.

106 Sonn (n 81) 136.

107 Ibid.

108 Kenney (n 100) 4; Sonn (n 81) 136.

109 Khadduri (n 6o) 68; Al Ghunaimi (n 6o) 141.
} 
their wealth as lawful. ${ }^{110}$ This is thought to be the first time in Islamic history in which an innovation (bid'a) which deviated from Islamic teaching (i.e. practicing takfir against fellow Muslims) had been made. ${ }^{111}$ This deviation however, is one of the fundamental principles followed by Da'esh.

Muslim jurists suggest that the main characteristic, which led the Khärijites to sway from the path of Islam, was the superficial understanding of the Qur'ān and the Sunna. ${ }^{112}$ Caliph 'Ali also alluded to the intentional nature of their misinterpretations during the exchange between them in which they used the Qur'ānic expression 'la hukm illa li-lläh' when protesting against him. To this he replied, 'a word of truth in which falsehood was intended'. These same characteristics apply to many of the followers of Da'esh.

Thus, the Khärijites set a dangerous precedent; rejecting the validity of a Muslim's belief in Islam because one does not adhere to the strict literalist interpretation which they themselves viewed as correct. This forms nothing short of a baseless justification to engage in violent jihād against the innocent and is an act which is orchestrated by many radical terror groups including Da'esh. Their view reflects that of the Kharijites in that the land of Islam had become a land of non-Muslims so all those who live in it are infidels and as a consequence their killings and the confiscation of their wealth is lawful. ${ }^{113}$ A member of the Khârijites who quit the group was considered an apostate and was condemned to death. Unsurprisingly the same view is held by Da'esh. In the propaganda magazine of Da'esh we read: 'As such, anyone who rebels against its [the Caliphate] authority inside its territory is considered a renegade, and it is permissible to fight him after establishing the hujjah against him (i.e. clarifying his error to him with proof)'.114

According to the Grand Mufti of Egypt, the shedding of the blood of innocent people by the Da'esh; the brutal slaughter of women and children and challenging the authority of the state; the attacks on mosques, and labelling these atrocities jihād are all a continuation of the Kharijites doctrine and ideology. ${ }^{115}$ Since then Da'esh has been described as the modern-age Khärijites. ${ }^{116}$ In response, Da'esh however dedicated almost one third of the second issue

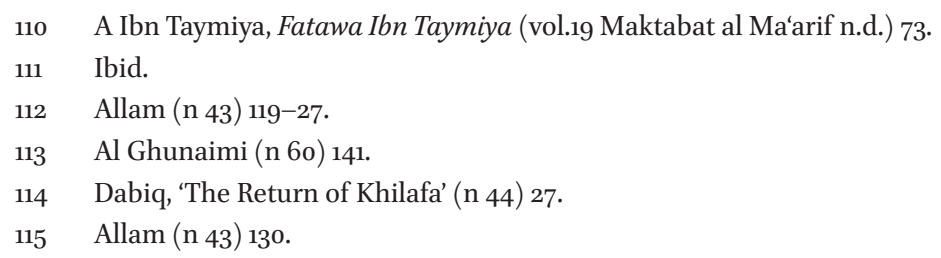

116 A. Mamouri, 'Who are the Kharijites and What do they have to do with Is?' Al-Monitor: The Pulse of the Middle East (8 January 2015) <www.al-monitor.com/pulse/originals/2015/ o1/islamic-state-kjarijites-continuation.html>. 
of its propaganda magazine, Dabiq, to refute a claim of the same kind made against the group by the leader of the Jawlāni Front in 2014. ${ }^{117}$ The rebuttal by Da'esh was not substantiated with arguments but was solely based on calling the leadership of the Jawlānī Front to participate in a mubāhalah (supplicating Allah for his curse to be upon the deceitful party) together with Da'esh spokesman al-'Adnān̄̄.118

\section{Dissecting the Ideology of Da'esh: The Jihādī-Salafism Movement}

The following sections will discuss in brief the Salafist ideology and in particular the jihādi-Salafist movement to draw potential parallels with Da'esh ideology on jihād.

\section{Salafism}

The term Salafism derives from the expression al-salaf al-salih (the pious ancestors) and is a form of Islamic revivalism. ${ }^{119}$ A distinctive Salafi intellectual genealogy extends to medieval times; the writings of the Syrian Hanbali scholar Ibn Taymiyya (d.1328) and his students provide the core theological corpus. ${ }^{120}$ Taymiyya described following the way of the Salaf as interpreting 'literally the Qur'anic verses and hadiths that relate to the Divine attributes, and without indicating modality and without attributing to him anthropomorphic qualities.'121 The Salafist dimension can be found in Da'esh theology in their belief that the manner in which they practice Islam is more puri$\tan$ and rigorous than that of other Muslims, so much so in fact, that their view is the only authentic interpretation of the religion. As is the case for all Muslims, the fundamental component running through the belief of Salafism

117 Dabiq, 'The Flood' (n 35) 20-30.

118 Ibid. Another attempt to refute such claim is found in 'A Call to Hijra' (Dabiq, issue 3, Shawal 1435) 10-11 <www.clarionproject.org/news/islamic-state-isis-isil-propaganda-mag azine-dabiq $>$.

119 T. Hegghammer, 'Jihadi Salafis or Revolutionaries? On Theology and Politics in the Study of Militant Islamism' in R. Meijer (eds), Global Salafism: Islam's New Religious Movement (Columbia University Press 2009) 244-266.

120 C. Bunzel, 'From Paper State to Caliphate: The Ideology of the Islamic State', The Brookings Project on U.S Relations with the Islamic World, No.19 (2015) 8.

121 W. Shepard, 'Salafi Islam: The Study of Contemporary Religious-Political Movements' in C. Bennet (eds.), The Bloomsbury Companion To Islamic Studies (Clinton Bennet and Contributors 2013) 163-184, 165 . 
is the doctrine of God's oneness (tawhid). ${ }^{122}$ Salafis principally criticise other Muslims for corrupting the faith with beliefs and practices that they see as denying tawhid. The idea that most Muslims despite professing tawhid do not follow or even understand it can be found in the following words of Mohamad bin Abdel Wahhab, the founder of original Wahhabism:

During [my time as a student of religion] I did not know the meaning of la ilah illa Allah; neither did I know the meaning of Islam. This was also true of my teachers; no man among them knew what this meant. If any of Al-'Aridh's ulema [Riyadh and its surroundings, also known as Al-Yamamah region] claims that he knew what la ilah illa Allah meant, or knew the meaning of Islam before this time, or claimed that one of his teachers knew what it meant, he, then, had lied, fabricated and given credit where credit wasn't due. ${ }^{123}$

In this sense Wahhabism presented itself as a correction to widespread jahilyyah (ignorance) declaring anyone who did not follow it as infidel, including the Hanbali jurists. ${ }^{124}$

Salafis believe that true Islam is found in the teachings and understanding of religious texts provided in the words and deeds of the first three generations of Islam, namely the sahabah, al-tabi'un and tabi'al-tabi'un..'125 Any kind of innovation in behaviour (bid'a), be it celebrating the birth of the Prophet Muhammad, commiserating the death of a saint, or applying tenets of democracy, is in their view unacceptable to God and dangerous to the Islamic faith.

The fundamental tenets which are central to Salafism and thus, lay at the core of Da'esh ideology are 'the call to return to the authentic practices and beliefs of the first generation of Muslims (al-salaf al-salih); the need to diminish unbelief; the belief that the Qur'ann and Sunna are the only valid sources of religious authority; the imperative to rid Islam of heretical innovations (bid'a);

122 B. Haykel, 'On the Nature of Salafi Thought and Action' in R. Meijer (eds.), Global Salafism: Islam's new Religious Movement (Hurst \& Company 2009) 38-39; N. Shama, 'Al-Jama 'Al-Islamiya And The Al-Jihad Group in Egypt' in J.L. Esposito and E. El-Din Shahin (eds), The Oxford Handbook of Islam and Politics (oup 2013) 608.

123 Bin Qasim, Sheikh Abdurrahman, (ed.), Ad'durar As'samiyah fi Al-Ajwibah An'najdiyah [The Shining Pearls in the Najdi Answers], vol. 10, (Alqassem Publishers 1996) cited in Bader Al-Ibrahim, (n 74) 413.

124 Bader Al-Ibrahim, (n 74) 413.

125 Bernard Haykel, 'IsIs: A. Primer' (Princeton Alumni Weekly 3 June 2015) 4 <www.paw. princeton.edu/article/isis-primer>. 
and the belief that specific answers to all conceivable questions are found in the Qur'ān and Sunna'.126

Salafism evolved further as it progressed into the twentieth century, becoming the Islamist-Salafism represented by the thought of the Muslim Brotherhood. This saw the goals of Modern-Salafiya descend from an intellectual level to one that can be disseminated among the people by way of $d a^{\prime} w a h$ (preaching/invitation to Islam). ${ }^{127}$ It is important to note that the IslamistSalafist movement as well as the modernist-Salafiya movement did not preach or advocate armed violence. However when this school of thought is combined with the school of $j i h \bar{a} d$, the military dimension becomes essential. ${ }^{128}$

\section{The Jihādī-Salafism Movement}

The core tenets of the jihādi-Salafism movement are composed of Wahhabiinspired Sunni fundamentalism 'combined with a revolutionary program of overthrowing un-Islamic regimes in the Muslim world, as well as irredentism aiming at expelling non-Muslim military presence and influences from Muslim lands.' ${ }^{29}$ Abu Muhammad al-Maqdisi, one of the most influential living jihâd $\bar{\imath}$ theorists and the key contemporary ideologue in the jihâd $\bar{\imath}$ intellectual sphere, defines the movement as 'a current which unites the call to monotheism in all its aspects with jihad for that purpose at the same time'. ${ }^{130}$ Whilst both non-violent Salafism and jīhadi-Salafism strictly adhere to absolute monotheism, it is through the exclusive utilisation of militant jīhād as a manhaj [methodology] to establish an al-dawlatuh al-Islämiyyah [Islamic

\footnotetext{
126 Shama (n 122) 608.

127 P. Shinar and W. Ende, 'Salafiyya' in P. Bearman et al. Encyclopaedia of Islam (2nd edn, Brill 2010).

128 Ibid.

129 P. Nesser, 'Abū Qatāda and Palestine' (2013) 53 Welt des Islams 416, 417; Q. Wiktorowicz, 'The New Global Threat: Transnational Salafis and Jihad' (2001) 8 Middle East Policy 18-38; Q. Wiktorowicz, 'Anatomy of the Salafi Movement' (2006) 29 Studies in Conflict and Terrorism 207; A. Moghadam, 'The Salafi-Jihad as a Religious Ideology' (Combating Terrorism Centre at West Point February 2008) 14-17. <www.ctc.usma.edu/v2/wp-content/uploads/ 2010/06/VolıIss3-Art5.pdf>; J. Wagemakers, A Quietist Jihadi: The Ideology and Influence of Abu Muhammad al-Maqdisi (CUP 2012).

130 F. Onuoha, 'Boko Haram and the Evolving Salafi Jihadist Threat in Nigeria' in M.-A. Perouse de Montcol (eds), Boko Haram: Islamism, Politics, Security and the State in Nigeria (African Studies Centre 2014) 158-192.
} 
state] in accordance with absolute monotheism, which places the latter at the top of the extremist hierarchy. ${ }^{131}$

Adamant in the call for the revival of the authentic Muslim society, the objective of the jithadi-Salafist movement is composed of two tiers; religious and political. This involves eliminating shirk through violent jihäd in order to restore the deviation from the correct path delineated in the Holy Scriptures. ${ }^{132}$ The pivotal crux which distinguishes the non-violent Salafis from the radical jithadi-Salafist movement derives from their approach to the question of the exercise of God's sovereignty. The notion that ruling by other than God's laws or replacing the Shariah with secular laws falls under the banner of major unbelief is fundamental to the latter while moderate Salafis believe that ruling by other than God's laws is only minor unbelief, preventing the permissibility of making a declaration of takfïr. Thus, Salafi-jihādīs interpret any attempt by political rulers to trade away the Shariah for secular laws or to govern by democracy as an act of profanity and polytheism, in other words, major unbelief.

Thus, the adherents of the jihādì-Salafist movement transform their religious philosophy into jihād through the radical interpretation of the doctrine of takfir. This interpretation creates an obligatory duty to declare takfir upon those who have deviated from ruling in accordance with God's sovereignty and have instead disregarded God's laws (tabdīl shara' Allāh) by conferring upon themselves the authority to make tahlīl and tahrim (declaring something to be either permissible or impermissible in a way that contradicts the divine legislations of God). ${ }^{133}$ The consequence of usurping the divine attribute of God 'the legislator' (al-Hākim) for themselves, sees them categorised as infidels, apostates (murtaddūn) and an object that is worshipped, followed and obeyed as a partner beside God țāghūt (plural: țawāghīt). ${ }^{134}$ Muslims are consequently obliged to disbelieve in the political regimes ruling with secular laws, show an open display of enmity, disavowal and hatred before waging

131 S. Lacroix, 'Between Revolution and Apoliticism: Nasir al-Din al-Albani and his Impact on the Shaping of Contemporary Salafism' in R. Meijer (ed), Global Salafism: Islam's New Religious Movement (Columbia University Press 2009) 58-80; J. Olidort, 'The Politics of "Quietist" Salafism', The Brookings Project on U.S. Relations with the Islamic World (February 2015) <www.brookings.edu/wp-content/uploads/2016/07/Brookings-Analysis-Paper_Ja cob-Olidort-Inside_Final_Web.pdf>.

132 Onuoha (n 130) 158-192.

133 A. Kassim, 'Defining and Understanding the Religious Philosophy of jihādī-Salafism and the Ideology of Boko Haram' (2015) 16 Politics, Religion \& Ideology 173, 181.

134 See J.J.G. Jansen, The Neglected Duty: The Creed of Sadat's Assassins and Islamic Resurgence in the Middle East (Macmillan Publishing 1986). 
jihād against the regimes and its supporters - all of which are considered fundamental criteria for the validity of their testimony of faith. ${ }^{135}$

The underling theological characteristics common amongst many of the contemporary radical movements are bound together by the jīhadi-Salafism creed and are built upon a radical interpretation of the takfiri doctrine. However, it is the extremity with which Da'esh declares the infidelity of Muslims and non-Muslims which distinguishes this group from other radical organisations, such as Al-Qaeda. Through a totalitarian and relentless adherence to declare takfir, the puritanical methodology of Da'esh has led to the supposedly permissible killing of thousands of civilians under the banner of jihād.

\section{Jihàd and Resort to War in the Eyes of Islamic International Law}

The doctrine of jihād has been viewed as one of the most misinterpreted and extremely complex terms in the history of Islamic legal discourse. ${ }^{136}$ Today, the notion of jihād often provides little more than a carte-blanche justification for going to war for reasons of realpolitik. ${ }^{137}$ The rise of ideological extremism in the Muslim world and the constant media attention have distorted the notion of jihād in such a manner that it has led to the misconception that the doctrine provides a justification to engage in barbaric war. In fact, this is a monstrous betrayal of its true Islamic roots. Da'esh has taken an iconic, emotive, Islamic term and used it as its call to arms, transforming jihād into a revolutionary murderous doctrine, painted over with a broad brush of theological colour to give it the appearance of legitimacy. ${ }^{138}$ The predominant aim of this section is to undermine the inaccurate interpretation of jihād explicitly used by Da'esh to justify the war they wage against their enemies.

In order to refute the religious justifications implemented by Da'esh one must analyse the meaning of jih $\bar{a} d$, paying specific attention to its theological

\footnotetext{
$135 \operatorname{Kassim}\left(\mathrm{n}_{133}\right) 185$.

136 For a comprehensive work that represents the juristic genre of ikhtiläf (disagreement) literature on jihad see Y.S. Ibrahim (trs), Al-Tabarìs Book of Jihād: A Translation from the Original Arabic (The Edwin Mellen Press 2007).

137 A.A. Sachedina, 'From Defensive to Offensive Warfare: The Use and Abuse of Jihād in the Muslim World' in J.I. Coffey and C.T. Mathewes (eds), Religion, Law and the Role of Force (Transitional Publishers 2002) 31. For different views on the meaning of jihad by western and Muslim scholars see Rehman, (n 75) 51-60.

138 M.C. Bassiouni, 'Evolving Approaches to Jihād: From Self-Defense to Revolutionary and regime-Change Political violence' in Bassiouni and Guellali (n 38) 11.
} 
evolution namely the three stages of military jiha $\bar{d}$, in order to understand its correct application. However, in this discussion, the notion of jihād must not be analysed in isolation, for alongside its own development, the concept of 'just war' in international law was also adjusted. Indeed, until the 2oth Century, the right to war was an accepted right and privilege of all States. It was not until 1928, when the total devastation of the First World War had shaken the world that attempts to curb that right emerged, through the Kellogg Briand Pact. ${ }^{139}$ Over the 21st Century numerous successive attempts at regulating war have paved the way for what is prescribed by modern international law, however they have not been universally effective. The Nuremburg Principles were followed by the United Nations Charter which attempted to bind the signatories to a set of protocols making aggressive use of force illegal.

International treaties have further prohibited war crimes or the acquisition of land by force and they also regulate the conduct of war through the 1949 Geneva Conventions and other treaties. However, wars are still fought all over the globe with drastic deviations from the rules of engaging in warfare. ${ }^{140}$

\section{Spiritual and Military Jihād in the Qur'ān}

Jiha ad, both linguistically and as a technical term, means 'struggle', and is etymologically related to the words mujahadah, which also means struggle or contention, and ijtihad, which is the efforts by jurists to arrive at correct judgments in Islamic law. ${ }^{141}$ These terms derives from the verb jahada and the abstract noun, juhd which means the 'exerted', or in its juridical-theological meaning, the exertion of one's power in Allah's path. ${ }^{142}$ This is commonly understood to involve someone who is diligent in the pursuit of a praiseworthy objective and whose spiritual, intellectual and physical endeavours reflect a higher purpose in the pursuit of the undertaking. ${ }^{143}$

The word itself comes from the root $\mathrm{j} / \mathrm{h} / \mathrm{d}$, which in Arabic means to exert the most effort. This is a general term as one can exert effort in a variety of ways in fulfilling their goals and ambitions. ${ }^{144}$ Studies of the Qur'an's usage of the term jihād and its derivatives reveal that it includes five different forms with a similar meaning (namely, jahada, jahd, juhd, jihād, mujah-

\footnotetext{
$139 \operatorname{Dagli}(\mathrm{n} 41) 70$.

140 Ibid.

141 Ibid. 58; Bassiouni (n138) 15 .

142 Khadduri (n 6o) 55 .

143 Bassiouni (n 138) 16.

144 Allam (n 43) 8.
} 
idun) appearing forty-one times in eighteen chapters (surahs). ${ }^{145}$ Contrary to popular Western belief, ${ }^{146}$ the term is not synonymous with war or fighting since exertion in Allah's path can be achieved by peaceful means. ${ }^{147}$ The Arabic equivalent of 'war' is 'harb' whilst the equivalent of fighting is 'qital.'148 It is important to distinguish between the three as the confusion surrounding these lexical terms has contributed to the common misconception that Islam is a religion of the sword, rather than a religion of peace.

References to jihād can be found in 24 verses in the Qur'än, most of which urge a spiritual struggle, such as focusing on being steadfast in sacrifice and faith, whilst some verses refer to jihäd in the sense of armed resistance against the enemies of Islam. ${ }^{149}$ The notion of 'exerting one's power for God' opens up doors for various alternatives as to what may constitute jihād. ${ }^{150}$ Since jihād incorporates both militant and non-militant elements, Muslim jurists have identified four ways in which a Muslim can perform their jihād obligation: by his heart, by his tongue, by his hands and by the sword. ${ }^{151}$ Fulfilling jihād by the heart is so significant in the eyes of God and his messenger, the Prophet Muhammad, that it is often referred to as the 'greater jihād' (al-jihād al-akbar). This is due to the required struggle against one's evil inclinations, to combat the devil and evade one's own lust and desires. ${ }^{152}$ The Prophet himself said: "The best struggle is to struggle against your soul and your passions in the way of God Most High.'153

Jihād of the sword on the other hand, known as the 'lesser jihād' (al-jihād al-asghar), requires taking part in actual fighting (qital) by sacrificing one's life in the name of Allah. ${ }^{154}$ This kind of military jihäd will be dealt with in details in the following sections. The fallacy surrounding the jiha $\bar{d}$ doctrine, which since the 1970's has been coined as a term attached to the ideological and military agenda of fundamentalists, has overshadowed the spiritual and peaceful

\footnotetext{
145 El Sayed M.A. Amin, Reclaiming Jihad: A Quranic Critique of Terrorism (The Islamic Foundation 2014) 79-80.

146 See Rehman (n 75) 51-6o examining different views on jihād by western scholars.

147 Khadduri (n 6o) 56.

148 M. Shaltut, 'The Qur'an and Combat' in Ghazi bin Muhammad et al. (n 41) 6.

149 Kamali (n 9o), 41.

150 O. Bakircioglu, Islam and Warfare: Context and Compatibility with International Law (Routledge 2014) 70 .

151 Hamidullah (n 57) 160; Khadduri (n 60) 57; O. Bakircioglu, 'A socio-legal Analysis of the Concept of Jihād' (2010) 59 International and Comparative Law Quarterly 440, 424.

152 Peters (n 55) 1; Khadduri (n 6o) 57.

153 See Muhammed Sa'id Ramadan al-Buti, Al-Jihād fi'l-Islam (Dar al-Fikr 2005) 21.

154 Khadduri (n 58) 15; Dakake (n 42) 99.
} 
underpinnings of Islam. ${ }^{155}$ In order to refute the justifications used by Islamic extremists it is paramount to note that the Prophet Muhammed placed jihād of the heart above the jih $\bar{a} d$ of the sword. When the Prophet Muhammad returned from the battle of Tabuk he said: 'We have returned from the lesser $j i h \bar{a} d$ to the greater jih $\bar{a} d$ '.156 Some have questioned the authenticity of this hadith; however, its meaning is confirmed by many others that place the efforts required in the spiritual life over that of physical combat. ${ }^{157}$

In order to combat the radical interpretation of the doctrine of jihād used by Daesh one must understand the theological roots and its evolution during the early period of Islam. When analysing the Qur'änic revelations of this period an objective approach to Qur'ānic exegesis must be taken where the exegete collects all the relevant verses and analyses them collectively, taking into consideration the environment in which they were revealed without imposing a personal interpretation on any verse. ${ }^{158}$

\section{The Theological Evolution of Jihād}

To truly understand jih $\bar{a} d$ as a means of waging war, it is important to look at the origins of Islam in which the doctrine gradually evolved. During the Prophet Muhammad's lifetime, the notion of jihäd acquired various meanings in line with the historical predicaments faced by the Muslim community. Accordingly, it moved from a pacifist character to that of a defensive one, whilst its spiritual value remained prevalent throughout. ${ }^{159}$ The Prophet Muhammad lived and received his early revelations in the city of Mecca. This period, known as the jahiliyyah (age of ignorance), was marked by polytheism, corruption, idolatry and immorality. It was here that the Prophet challenged the status quo, calling for justice and equality; he summoned the people to strive (jiha $\bar{a}$ ) to live a life based on Islamic principles. ${ }^{160}$ From 610-622 C.E. Muhammad practised and proclaimed a peaceful policy of nonresistance in the face of intensifying humiliation, cruelty and violence at the

\footnotetext{
155 A.A. Badawi, Islam Hadhari: A Model Approach for Development and Progress (MPH Publications 2006) 68: 'Muslim Scholars define jihād in terms of sustained effort to discipline one's own self in obedience to Allah.Jihād also implies endeavour to uphold social justice, peace and fair play...It is most unfortunate that some have narrowed the concept of jihād to be synonymous with qital, which concerns physical fighting'.

${ }_{156}$ See al'Ajluni, Kashf al-Khafa' (Dar Ihya al-Turath al-'Arabi, 1968) hadith no.1362.

157 Dagli (n 41) 61.

158 Shaltut (n 148) 3 .

159 Bakircioglu (n 151) 422.

160 Ibid. 426 .
} 
hands of the Quraysh; the dominant tribe of Mecca. ${ }^{161}$ In 622 Muhammad and his small community of followers embarked on hijra (emigration) to Medina, giving birth to a new stage of Islam and thus, creating the ummah. After two years of continuous persecution, Muhammad announced a revelation from Allah permitting Muslims to physically defend themselves through means of force. It is believed by scholars that the Quranic verse 22:39 contained the first transformational statement of permission: ${ }^{162}$

Verily Allah will defend (from ill) those who believe: verily, Allah loves not any that is a traitor to faith, or shows ingratitude. To those against whom war is made, permission is given (to fight), because they are wronged-and verily, Allah is most powerful for their aid.(they are) those who have been expelled from their homes in defiance of right (for no cause) except that they say, 'Our Lord is Allah' (Qur'ān 22:38-40).

It is evident from the wording of the above verse that Allah's permission to engage in qital was formed on the grounds of self-defence in the face of attack and oppression. By looking at the phrase 'to whom war is made' one can see that permission is only given to fight when the other party has initiated an aggressive war. This corresponds directly with the first Qur'anic passage on war, verse 2:190: 'Fight in the cause of Allah those who fight you, but do not transgress limits: for Allah loves not the transgressors' (Qur'ān 2:19o).

From looking at the origins of the term jihàd, one can see that the spiritual endeavour against oneself for piety, is a Muslim's foremost duty. It was not until circumstances changed during the Prophet's lifetime that the military dimension of jihād developed to mean the continuous resistance against aggression, persecution and protection of the freedom of religion. ${ }^{163}$ Furthermore, it must be remembered that the concept of 'mercy' forms the backbone of all Islamic rulings. ${ }^{164}$ It has been argued that all lawful qital is jihād; a legitimately approved and collective military struggle against evil, but not all jihād should be restricted to qital. ${ }^{165}$ There are no verses in the Qur'ān which permit the use of violence against non-combatants, irrespec-

\footnotetext{
161 J. Hayward, 'Warfare in the Qur'an' in Ghazi bin Muhammad et al. (n 41 ) 42.

162 S.H. Hasmi, 'Sunni Islam', in G. Palmer-Fernandez (ed.) Encyclopaedia of Religion and War (Routledge 2004) 217.

163 A.G. Hamid, 'Islamic International Law and the Right of Self-Defence of States' (2009) 2 Journal of East Asia and International Law 67, 73 .

164 Allam (n 43) 7 .

165 Dagli (n 41) 59 .
} 
tive of their religious beliefs. Thus, the Qur'ān forbids killing whilst stressing the sanctity of human life: 'Life, which Allah has made sacred' (Qur'ān 6:151). Concluding with the words of Bassiouni, "[f]rom the days of the Prophet, jihad was subject to conditions as to its rightfulness, which we would today call the right to legitimate self-defence.'166

\section{Jihād: A Perpetual State of War?}

The classical religious division of the world between 'the abode of Islam' (dār al-Islam) and the 'abode of war'" (där al-harb) has had a minimal effect on international relations in the modern day, however, it has formed the basis for non-state violence committed by extremists. As discussed above, whilst there are a number of references with regard to the conduct of Muslims towards non-Muslims in the Qur'ann as well as in the hadith, the classical distinction between the two abodes has no place in the Qur'an whereas the only hadith narration cited in its support cannot be found in the collections of the authentic hadiths. ${ }^{167}$ Such a 'dichotomous classification', was 'mainly based on the attitude of the Muslim state towards its enemies and friends' during this period.' ${ }^{168}$ Regardless of this, it forms the very heart of Da'esh ideological narrative. The concept is a legal and political structure developed by classical jurists through means of ijtihad (logical deduction and interpretation). Furthermore the Qur'annic and Prophetic narratives with regards to the relations between the two abodes were formulated by jurists in terms of the historical progress made by the Islamic community through its early

166 Bassiouni (n 138) 134.

167 T. Roeder, 'Traditional Islamic Approaches to Public International Law - Historic Concepts, Modern Implications' (2012) 72 Max-Planck-Institut fur auslandisches offenliches Recht und Volkerrecht 522, 527, 'it's occurrence in the body of hadith is in dispute, as this relates to a very small number of ahadith the authenticity of which is debatable and refused by the majority'. Amin (n 145) 94 (references omitted). As noted by Abou El Fadl: 'While Muslim jurists agreed that the authenticity of the Qur'an, as God's revealed word, is beyond any doubt, classical jurists recognized that many of the traditions attributed to the Prophet were apocryphal. In this context, however, Muslim jurists did not just focus on whether a particular report was authentic or a fabrication but on the extent or degree of reliability and the attendant legal consequences. Importantly, Muslim jurists distinguished between the reliability and normativity of traditions. Even if a tradition proved to be authentic, this did not necessarily mean that it is normatively binding, because most jurists differentiated between the Prophet's sacred and temporal roles'. K. Abou El Fadl, Reasoning with God: Reclaiming Shariah in the Modern Age (Rowman \& Littlefield, 2014) $\mathrm{xxxv- \textrm {i } .}$

168 Amin (n 145), 94 (references omitted). 
expansionist battles. ${ }^{169}$ As such, aggressive war against non-believers was ex post facto legitimised after the early conquests from the late 8th century $\mathrm{CE}$ onwards. ${ }^{170}$

This was in stark contrast to the original attitudes, during the time of the Prophet, when due to continuous persecution of the Muslim community, the desire to protect the ummah was the only goal which was juxtaposed with the use of force. ${ }^{171}$ It was furthermore in contrast with the earliest Sunni doctrine which allowed forceful jihād merely for self-defense and laid down the following conditions for the permissibility of the use of force against non-Muslim controlled areas: the existence of a threat to the Muslim ummah (community); opposing the propagation and practice of Islam; or/and a refusal to sign a peace treaty with the Muslim ummah. ${ }^{172}$ Muhammad al-Shaybani, known as the father of Islamic international law, thus laid down the regulations governing Islam's external relations based on the assumption that a state of war existed between the two abodes, but made no explicit statement that jihād was to be waged against the unbelievers solely on account of disbelief. Hence, it is not the disbelief, which warrants the use of force, rather the hostility demonstrated by the unbelievers against Islam, for example, persecution of the Muslims. ${ }^{173}$ As mentioned above, all classical jurists however, considered Muslim territory governed by non-Muslim law or non-Muslim rulers to be $d \bar{a} r$ al-hārb.

The very essence of the Salafi-jihadi creed to which Da'esh adheres, depicts that their engagement in war is fundamentally legitimate through jus ad bellum under Islamic international law. Da'esh as well as many other radical contemporary Islamist groups, all of which identify with Salafism, see jihād as a war to eradicate political barriers and the liberation of humanity from subjection to jahili man-made laws. A fundamental argument made on behalf of those in support of such thinking is that since the majority of classical jurists believed expansionary warfare as both permitted and obligatory, modern

169 A.E. Mayer, 'War and Peace in the Islamic Tradition and International Law' in J. Kelsay and J.T. Johnson (eds), Just War and Jihād: Historical and Theoretical Perspectives on War and Peace in Western and Islamic Traditions (Greenwood Press 1991) 195, 197; T.A. Falahi, The Quranic Concept of War and Peace (Kanishka Publishers 2004) 90-101.

170 A.A. Sachedina, 'The Development of Jihād in Islamic Revelation and History', in Johnson and Kelsay (n 81) 37; F.M. Doner, 'The Sources of Islamic Conception of War' in Johnson and Kelsay (n 81) 50 .

171 A.A. An-Na'im, Toward an Islamic Reformation: Civil Liberties, Human Rights, and International Law (Syracuse University Press 1996) 158.

172 Bassiouni (n 138) 27-28.

173 Sachedina $(\mathrm{n} 170) 43$. 
Muslims should also adopt this view. ${ }^{174}$ Sayyid Qutb argued that verses in the Qur'an which speak of peace or co-existence with unbelievers (e.g. Qur'ann $8: 61 ; 60: 8 ; 2: 190 ; 3: 64)$ were temporary, provisional rulings abrogated by the final ruling revealed ing:5 of the Qur'ān. ${ }^{175}$ In response to the view that the doctrine of jihād is a perpetual state of war, one scholar explained that:

They took the Qur'anic verses out of context and thus destroyed their significance. The Qur'an and the Sunnah ordered all-out war against the Arab pagans who were always referred to as Mushrikun (idolators or associators). Whenever the Qur'an speaks of these Arabs, it stresses their cruelty, treachery, hypocrisy, greed, savagery, etc. The Arabs who were the subject of these Qur'anic verses were mainly Bedouins who continually attacked and persecuted Muslims and betrayed their pledges... Islam developed an attitude of all-out war only against the Adnani bedouins and their Qurayshi leadership in their opposition to Islam. ${ }^{176}$

This kind of war was still self-defensive, even though it can be described as pre-emptive self-defence, since the Mushrikun were too unpredictable in their actions and broke by their pledges on such a continuous basis, that it would have been unreasonable to expect constructive diplomatic relations with them in order to avoid conflict. Here it becomes evident that Da'esh adherence is to a distorted interpretation of Islam, not its genuine meaning and is based on a misguided idea based on the realpolitik of the Abbasid period up until the demise of the Muslim hegemony.

Just as the Qur'än does not permit waging war on account of disbelief, it does not permit warfare as a means of promulgating Islam; rather it permits freedom of belief for all of mankind. ${ }^{177}$ However, this is not the position taken by Da'esh, which have specifically imposed the forceful conversion of Islam upon the Yezidi minority in Iraq. This directly flies in the face of Islamic teaching as the Qur'ān states: Unto your religion, and unto me my religion' (Qur'ān 109:6), and 'Whosoever will, let him believe, and whosoever will, let

174 A.F. March and N.K. Modirzadeh, 'Ambivalent Universalism? Ius ad Bellum in Modern Islamic Legal Discourse' (2013) 24 The European Journal of International Law 367, 373.

175 See S. Khatab, The Political Though of Sayyid Qutb: The Theory of Jahiliyyah (Routledge 2006).

176 A.H. Abu Sulayman, 'Towards an Islamic Theory of International Relations' (1994) 55 American Journal of Islamic Social Sciences 47.

177 According to Khaduri (n 57): 'Sarakhsī, the great commentator on Shaybāni's works, accepted the Shāfi'i doctrine that fighting the unbeliever was "a duty enjoined permanently until the end of time"'. 
him disbelieve' (Qur'ān 18:29), and 'There is no compulsion in religion. The right direction is distinct from error (Qur'ān 2:256).

The Qur'ānic verses reject any argument that Islam permits the forceful conversion of non-believers. Rather, it provides evidence to suggest that Islam is a religion of coexistence. However, the classical jurists such as Shafi'i have inspired the likes of Sayed Qutb in believing that the command to spread the word of Islam peacefully has been abrogated to permit the coercion of religious belief by the above mentioned Qur'annic verse 9:5. ${ }^{178}$ They further find evidence for the support of their argument in the following hadith:

I have been commanded to fight the people until they bear witness that there is no divinity but God and Muhammad is God's Messenger, perform the Prayer, pay the Alms. When they have done this their blood and property is safe from me, except by the right of Islam and their reckoning with God.

This hadith would appear to contradict the notion that Islam is a religion of peace, however arguments that use examples such as these to support the abrogation of the peaceful propagation of Islam lack authoritative character. The following Medinan verses, revealed after permission was given to the Muslims to resort to the use of force, make it clear that Islam endeavours for the truth to reach those yet to hear it, rather than forcing it upon them: ${ }^{179}$ 'But if they are disregardful, We have not sent you as a keeper over them. Your duty is only to deliver the message' (Qur'ān 42:48); 'And whether We show you a part of that which We promise them, or We take you [To us], it is for you to convey [the Message], and it is for us to do the reckoning' (Qur'ān 13:40).

In recent history, several nation-States with predominantly Muslim populations have gained independence by waging what could be described as a just jihād against foreign occupation and a colonial ruler, a concept which would fit under the right to self-determination in international law. In a similar vein, the mujahedeen launched a protracted campaign against the Soviets in order to the removal of Russian forces from Afghanistan. ${ }^{180}$ However Da'esh could not reasonably use this wider definition of defence of the ummah under the doctrine of jihād, for the following reasons. Even if Da'esh believed Muslims had been wronged by certain actions of Western governments, the

\footnotetext{
178 Dagli (n 41) 73 .

179 Ibid. 74.

180 L.A. Khan, A Theory of International Terrorism: Understanding Islamic Militancy (Brill 2006) 183 .
} 
fact that they are directing their aggression mainly against fellow Muslims and non-Muslim civilians, and not against those that have wronged them, takes away the possibility of using this wider notion of jihād as justification. Furthermore, instead of rectifying injustices, Da'esh is creating additional suffering and human rights abuses for millions of innocent people. Last but not least, Da'esh is bringing even greater involvement of outside forces into the ummah by attracting international response in the form of airstrikes or possibly even renewed Western occupation of majority-Muslim lands.

\section{Conclusions}

Instead of following the defensive idea of jihād as prescribed in the Qur'ān and the vast majority of authentic hadith, Is claim justification for its aggressive and murderous mission based mostly on the jurisprudence of the seventh century, which followed the expansionary aspirations of the ummah at that time. However even the said jurisprudence understood jihād as permitting warfare only against non-Muslims and apostates and strictly regulated in terms of jus in bello. ${ }^{181}$ Irregular warfare and terrorism against Muslims and non-Muslims alike on the other hand have been almost uniformly condemned in Islamic literature both classical and contemporary. ${ }^{182}$

Regardless of the terrorist element, the logic of a permanent state of war is neither realistic nor practical and with the evolution of the international landscape it has become obsolete. Due to the decentralisation of Islam which began to occur from the 1oth century onwards, the principle of jihād as a collective duty to wage war against the unbeliever retained little of its substance. ${ }^{183}$ Furthermore, our analysis of the theological evolution of the meaning of jiha $\bar{d}$ shows that its belligerent side has experienced radical departures from its original meaning in order to fit the early expansionist agenda. By explaining the defensive character of the Qur'änic narrative, this article has brought to light the perpetual misinterpretations in which the term jihād has come to be twisted even further in order to justify the endless violence perpetrated by various Islamist groups. In the same vein, Da'esh uses distorted applications of Islamic teaching in order to spread the territorial capacity of its control and to expand its version of Islam through means of forceful conversion and the cleansing of society from those Muslims who do not adhere

\footnotetext{
$181 \quad$ Sonn (n 81) 129 .

182 Ibid. 130.

183 Khadduri ( n $_{57}$ ) 59 .
} 
to its radicalisation. Rebelling against rulers of Muslim majority states, Is, just like the Muhakkimah, have been using the banner of jihād to adopt and implement its extreme interpretation of Islamic principles. The irony is that while its leaders go about declaring other Muslims to not be Muslim enough, Da'esh itself represent a group that has been rightly condemned as Khärijites, or in other words to have stepped outside of Islam by the rest of the Muslim community. The characteristically striking resemblance between Is and the primitive Muhakkimah reminds us of the cyclical nature of history and the need to effectively and authoritatively ascertain the true stance of Islam on these issues before a new group emerges with the same ideas.

A part of the problem lies in the fact that although Islamic teaching places comprehensive limitations on the lawful use of force, the seemingly nonlinear Qur'anic position combined with an ambiguous division between the views of Muslim jurists has left the Islamic ius ad bellum many times in an equivocal position. However, the separation of the world into dār al-Islam (abode of Islam) and dār al-harb (abode of war) reflects the historical context of the time in which politics followed an expansionary agenda. This was also influenced by the then international customary norm according to which it was considered a right of states to enter a state of war to ascertain an objective. ${ }^{184}$ Even in the rest of the world, it took centuries before the just war' doctrine could begin to limit the broad legal justifications for aggression, especially after undergoing secularism itself and renouncing the right to go to war for the sake of propagating one's religion. Through the development of treaties such as the UN Charter, military aggression for the acquisition of territory by law eventually became illegal. The same approach was established by the Qur'ān hundreds of years before, but has been neglected by those who seek to expand their power through manipulating religion ever since. Islam's vision of human society underlies its conception of international law. Man created by God, is born good and the Qur'ân maintains him in this natural quality. As such, war is considered as contrary to human nature, for the essential foundation of man's passage on this earth is peaceful. War, a reprehensible act for believers, may nevertheless be an unavoidable evil once it is necessary to repel an aggression and to defend Muslims when under threat, to thwart plots by their enemies to oppress and persecute them.

The Qur'anic concept of jihād almost entirely aligns itself with the principles of both Article 2(4) and Article $5^{1}$ of the UN Charter. ${ }^{185}$ Jihäd, like the UN

\footnotetext{
184 Dagli (n 41) 71-72.

185 S. Mahmoudi, 'The Islamic Perception of the Use of Force in the Contemporary World' (2005) 7 Journal of the History of International Law 55, 56.
} 
Charter, prohibits all use of force, except in very limited and exceptional circumstances, such as self-defence. However to a limited and reasonable extent, jihād extends a state's power and discretion beyond the strict regulations set forth in the Charter. Where the Charter demands that, in order to trigger the right to self-defence under Article 51, there must be an actual armed attack by a state or state actor, the rules of jihād permit war even in situation where the attack is carried out by non-state actors. ${ }^{186}$ Since the prohibition against aggressive war constitutes today's secular ius ad bellum norm, the religious justness of a given conflict clearly bears no relevance in determining whether the use of force by a State complies with the UN Charter. ${ }^{187}$ Under the UN collective security system, the concept of bellum justum is replaced by that of bellum legale. ${ }^{188}$ As a result, the contemporary international regulation of warfare places no authority on the religious, theological and political justifications for resorting to the use of force. Under international law, therefore, even legitimate jiha $\bar{d}$ cannot pass for a legal justification if it falls outside the boundaries of the Charter. However, for groups such as Is and its supporters, international law and secularism present sinful systems, which are of no value to them. It is therefore important to stress that the actions of these extremist militants groups have no justification, even under the broadest definitions of permissible belligerent $j i h \bar{a} d$.

\footnotetext{
186 Charter of the United Nations, Chapter VII, Article 51.

187 Bakircioglu (n 151) 157 .

188 J.L. Kunz, 'Bellum Justum and Bellum Legale' (1951) 45 American Journal of International Law 528, 532 .
} 